NBER WORKING PAPER SERIES

\title{
HEALTH INSURANCE ELIGIBILITY, UTILIZATION OF MEDICAL CARE, AND CHILD HEALTH
}

\author{
Janet Currie \\ Jonathan Gruber
}

Working Paper No. 5052

\author{
NATIONAL BUREAU OF ECONOMIC RESEARCH \\ 1050 Massachusetts Avenue \\ Cambridge, MA 02138 \\ March 1995
}

We thank Aaron Yelowitz for graciously providing some of the data on Medicaid expansions, Andres Villaquiran for research assistance, and Josh Angrist, David Cutler, George Jakubson, Douglas Holtz-Eakin, Larry Katz, Jim Poterba, Aaron Yelowitz, and seminar participants at Cornell and the NBER for helpful comments. Janet Currie gratefully acknowledges financial support from the Alfred P. Sloan Foundation, and from the National Science Foundation (SES9122640). Jonathan Gruber gratefully acknowledges financial support from the National Institute of Aging. This paper is part of NBER's research programs in Health Care and Public Economics. Any opinions expressed are those of the authors and not those of the National Science Foundation, the National Institute of Aging, or the National Bureau of Economic Research.

(C) 1995 by Janet Currie and Jonathan Gruber. All rights reserved. Short sections of text, not to exceed two paragraphs, may be quoted without explicit permission provided that full credit, including $\odot$ notice, is given to the source. 
Public concern about the health of children is one of the driving forces behind efforts to reduce the rate of uninsurance in the U.S.. High rates of child mortality and morbidity suggest that American children do not receive the same quantity or quality of health care as children in other developed countries. For example, at 8 per 1000 , the infant mortality rate in the United States is the highest in the developed world. Compared with Canadian children, U.S. children 1 to 4 years of age also have a $14 \%$ higher mortality rate. And U.S. children under 15 years of age have $28 \%$ more disability days and 44\% more bed days than Canadian children (Kozak and McCarthy, 1984). These problems are particularly acute among African-American children, whose child mortality rates are $63 \%$ higher than those of whites.

Since the uninsured are known to receive less health care than the insured, a potential explanation for this shocking state of affairs is that as many as $30 \%$ of poor children are without health insurance of any kind (Bloom, 1990). Hence, the debate over reforming the U.S. health care system has increasingly emphasized health insurance for children (Boston Globe, September 12, 1994). Absent from this debate, however, is convincing evidence that increased eligibility for public insurance will actually improve the health of children.

Increased eligibility may not translate into health improvements for two reasons. First, increases in eligibility do not automatically increase the utilization of medical care or the efficiency with which medical care is delivered. A large literature documents the fact that individuals do not always take-up public assistance benefits for which they are eligible (Blank and Card 1991; Blank and Ruggles, 1993). This problem may be more severe among groups who have not traditionally received public assistance; these groups may be both less well informed about public program availability and more reticent to avail themselves of public "handouts". Furthermore, even if eligibles take up their benefits, many physicians do not treat publicly insured patients, possibly 
because public insurance programs generally reimburse at rates far below private fee levels. ${ }^{1}$ This problem is exacerbated by the fact that many of the patients who would be made eligible for public insurance are concentrated in areas that are underserved by physicians (Fossett and Peterson, 1989; Fossett et al., 1992). ${ }^{2}$ As a result, care may be delivered inefficiently to Medicaid patients, with excessive (expensive) visits to hospital outpatient departments and emergency rooms (Long et al., 1986).

Second, increases in the utilization of care will not necessarily improve child health -- for example, a number of studies suggest that much of the acute care received by children is inappropriate and may have little health benefit. ${ }^{3}$ Lurie et al. (1984) and Bindman et al. (1992) document positive effects of insurance on adult health, but a randomized trial (Newhouse, 1993) suggested that insurance was of little benefit. However, the first two studies did not look at children, and there were too few children involved in the randomized trial for any firm conclusion regarding child health to be drawn (Valdez, 1985).

Several recent papers have shown that children who are uninsured have lower utilization levels, a less efficient distribution of utilization across sites of care, and worse health outcomes (Kasper, 1986; Short and Lefkowitz, 1992; Mullahy, 1994). But since the uninsured are likely to differ from the insured in both observable and unobservable respects, it difficult to draw causal inferences from these types of comparisons. Furthermore, insurance coverage itself may be a

${ }^{1}$ See Currie, Gruber, and Fischer (1995) for evidence on the relationship between infant mortality and Medicaid fee policy.

2 For example, Fossett et al. (1992) compared Chicago neighborhoods with $50 \%$ of the population on welfare to neighborhoods with $10 \%$ of the population on welfare and found that there were twice as many physicians practicing in the wealthier areas (on a per child basis).

${ }^{3}$ Kemper (1988), for example, finds that $21 \%$ of pediatric hospitalization days were of "doubtful necessity", and that this fraction is higher for insured than for uninsured children. 
function of health status, leading to endogeneity bias in estimates of the effects of insurance on health, and on the utilization of medical care.

In this paper, we attempt to identify the effects of insurance coverage by drawing on dramatic recent expansions of Medicaid eligibility for low income children. Medicaid is a federal-state matching entitlement program that provides health insurance to the poor. Historically, eligibility for Medicaid was tied to the receipt of cash welfare payments under the Aid to Families with Dependent Children program. Hence, eligibility was effectively limited to very low income women and children in single parent families. Beginning in 1984, states were first permitted and then required to extend Medicaid coverage to other groups of children. By 1992, states were required to cover children below age 6 in families with incomes up to $133 \%$ of the federal poverty line, and children between ages 6 and 19 with family incomes up to $100 \%$ of the poverty line; states also had the option of covering infants up to $185 \%$ of the poverty line. ${ }^{4}$ Since states have taken up these options at different rates, there is substantial variation in Medicaid eligibility thresholds by state, year, and age of child that can be used to identify the effects of the expansions.

We use this variation to address the effects of expanding public insurance eligibility for children during the 1984 to 1992 period. In Part I, we use data from the Current Population Survey (CPS) to measure increases in eligibility that resulted from state Medicaid policy changes over this era, and to examine the extent to which these increases in eligibility were translated into increases in Medicaid coverage. ${ }^{5}$

\footnotetext{
${ }^{4}$ States received federal matching funds for coverage of these groups. However, some states have extended coverage to children above $200 \%$ of the poverty line, using state only funds.

5 As we emphasize in Currie and Gruber (1994), the effectiveness of eligibility expansions depends on the extent that the newly eligible take up their benefits. In that paper, we show that many pregnant women who became eligible for Medicaid failed to take up their coverage.
} 
The main focus of the paper is on the estimation of the effects of Medicaid eligibility on the utilization of care using the National Health Interview Survey (NHIS), a large, nationally representative data set. We describe these data in more detail in Part II. We also present our identification strategy: we use demographic and economic information from the NHIS to impute Medicaid eligibility for each child, and then use the fraction of children in the same state, age, and year who are eligible for Medicaid, calculated from the CPS, as an instrument for our individual eligibility measures. In this way, we solve both the omitted variables and endogeneity problems that bias Ordinary Least Squares (OLS) estimates.

In Part III, we use this empirical strategy to measure the effect of Medicaid eligibility on medical utilization and on the site of care. In Part IV, we extend our analysis to health outcomes, estimating the effect of Medicaid eligibility on both subjective health measures from the NHIS and objective state-level data on child mortality. Finally, in Part V, we assess the extent to which increases in Medicaid eligibility have narrowed racial and educational disparities in utilization and health. ${ }^{6}$

\section{The Medicaid Expansions}

\section{Legislative Background}

Historically, Medicaid eligibility for children has been tied to participation in the Aid for Families with Dependent Children program (AFDC). This linkage with AFDC restricted access to the program in three ways. First, despite the existence of the AFDC-Unemployed Parents program (AFDC-UP) which provides benefits to households in which the primary earner is unemployed,

\footnotetext{
${ }^{6}$ Currie and Thomas (1995) find that Medicaid coverage reduces racial disparities in the utilization of routine checkups. However, it raises the number of visits for illness only among white children, thus increasing racial disparities in the treatment sick children receive.
} 
AFDC benefits are generally available only to single-parent households. ${ }^{7}$ Second, income cutoffs for cash welfare vary across states, and can be very low. For example, in 1984, the cutoff for a family of 4 in South Carolina was only $29 \%$ of the poverty line. Third, the stigma of applying for cash welfare programs may have prevented eligible families from receiving Medicaid benefits (Moffitt, 1992).

In some states, children could also qualify for Medicaid under state Medically Needy or Ribicoff programs. The Medically Needy program relaxed the income criteria for eligibility by covering people who would have been eligible for AFDC if their incomes were lower, but who had large medical expenditures that brought their "net income" below program thresholds. The Ribicoff option allowed states to cover children in two-parent families who met the AFDC income criteria.

Beginning with the Deficit Reduction Act of 1984 (DEFRA '84), which became effective in October 1984, the linkage between AFDC coverage and eligibility for Medicaid has been gradually weakened. DEFRA ' 84 eliminated the family structure requirements for Medicaid eligibility for young children, by requiring states to cover children born after September 1, 1983 who lived in families that were income-eligible for AFDC. DEFRA was followed by a series of measures that raised the income cutoffs for Medicaid eligibility, first at state option, and then by federal mandate. These options are described in detail in Appendix Table 1.

The important point to note is that states took up these options at different rates, so that there was a great deal of variation across states in both the income thresholds and the age limits governing Medicaid eligibility. Appendix Table 2, drawn from Yelowitz (1994), illustrates this point. As of January 1988, 26 states had taken advantage of the options described above to extend Medicaid

${ }^{7}$ Not every state had an AFDC-UP program over our sample period, and among those that did, eligibility requirements were strict. As a result, as of 1990 only $5 \%$ of the AFDC caseload qualified under this program (U.S. House of Representatives, 1992). 
eligibility to previously ineligible children. By December 1989, all 50 states had expanded Medicaid eligibility -- however states like Colorado covered only infants in families with incomes up to $75 \%$ of the poverty line, while more generous states, like California, covered children up to age 5 in families with incomes up to $100 \%$ of poverty. We will exploit this variation in order to identify the effects of the Medicaid expansions.

\section{Effects on Eligibility}

A natural first question about these Medicaid policy changes is whether they had a significant effect on the fraction of the population eligible for the program. To answer this question, we use data from the CPS March surveys for 1985 to 1993. The CPS collects information on demographic characteristics as well as income and labor force data for the previous year, so that our analysis will cover the 1984 to 1992 period. We impute eligibility to each child in the CPS using the algorithm described in Appendix A. For this calculation and throughout the paper, children are defined as those less than 15 years old, in order the avoid the problem of children having children. ${ }^{8}$

The results of our calculation at the national level are summarized in the first column of Table 1. There was a dramatic increase in Medicaid eligibility over this period; eligibility doubled between 1984 and 1992, and almost 1/3 of all children in the U.S. were eligible by the end of the period. Some of the increase came from DEFRA and other state law changes between 1984 and 1987, but the bulk came from the expansions to higher income groups between 1987 and 1992 . Some of this later increase, of course, resulted from the recession at the end of the period, which lowered family incomes and made more children eligible at each level of legislative generosity. In

\footnotetext{
${ }^{8}$ Due to the way that the expansions were phased in, pregnant teens could have been eligible for Medicaid coverage of their pregnancies even if family income was too high for the teen to be eligible otherwise. We study the effect of Medicaid coverage for pregnancies in Currie and Gruber (1994).
} 
order to separate business cycle effects from the effects of legislative change, we also estimate the fraction of the 1984 population that would be eligible under each year's laws. These estimates are shown in column 2. The two columns are very similar, suggesting that most of the increase in eligibility was the result of legislative changes.

In addition to the time series variation in eligibility, there is substantial heterogeneity across the states, as shown in Appendix Table 3. This table lists the fraction eligible in each state in 1984 and 1992, as well as the change over the period. While eligibility rose substantially nationwide, it actually fell in two states, Pennsylvania and Wisconsin. When states are ranked by the fraction covered, the correlation between the rankings in 1984 and 1992 is only 0.16 ; the median state moved 14 positions in this ranking. This heterogeneity reflects both changes in state policy and statespecific changes in economic conditions. Thus, in the last three columns, we once again provide eligibility estimates calculated holding population characteristics constant at their 1984 levels. The results are very similar. Nevertheless, below, we present a methodology for identifying our models using the state policy changes only, in order to control for both the national recession and state economic conditions.

\section{Effects on Coverage}

As highlighted in the introduction, increases in Medicaid eligibility do not automatically translate into increases in insurance coverage. In order to examine the takeup of Medicaid coverage by newly eligible children, we use a question about Medicaid coverage from each March's CPS."

\footnotetext{
${ }^{9}$ The question asks whether the individual was covered by Medicaid at some point in the previous year; we measure Medicaid eligibility using income information from the previous year. There may be timing problems in our measures of individual eligibility, since income fluctuations during the year can make an individual eligible at one point during the year, even if they are ineligible using average annual income. Approximately $20 \%$ of those who report Medicaid coverage are deemed
} 
The second column of Table 1 shows Medicaid coverage over time. Overall, coverage did rise, but not nearly as steeply as eligibility; the increase in coverage was approximately $1 / 2$ as large as the increase in eligibility. Coverage was actually flat from 1984 to 1988 , and rose sharply thereafter. This time trend follows the business cycle, suggesting that the increase in coverage cannot be automatically attributed to changes in Medicaid policy. In order to control for the business cycle as well as for observable non-policy related determinants of individual eligibility we estimate models of Medicaid coverage that include year dummies as well as controls for race, gender, mother's education (high school dropout, high school graduate only, some college), family income $(\$ 10,000$ intervals up to $\$ 50,000)$, child age, and state..$^{10}$

The estimation results are presented in Table 2. As the first column shows, making a child eligible for Medicaid over the 1984 to 1992 period increased the probability that he or she was covered by insurance by approximately $30 \%$. This figure is substantially below the takeup rates estimated for other social programs, but it is not strictly comparable, since we are calculating the marginal effect of policy changes, rather than the average takeup for a given level of eligibility.

These regressions may be subject to some remaining omitted variables bias; for example, a recession in a state will cause both eligibility and coverage to rise simultaneously. We address this problem by instrumenting eligibility in the second column of Table 2. The instrument that we use measures the legislative generosity of Medicaid policy in a given state in a given year, for each

ineligible by our imputation procedure. Note also that this information became much more reliable after 1986, since surveys before March 1988 did not gather complete information about insurance coverage obtained through someone other than the head of the household. The results presented below, however, are not sensitive to the restriction of the sample to 1987 onwards.

${ }^{10}$ The results are very similar if the regressions are estimated as probit or logit models instead. We use mother's education because almost every child in our sample has a mother present but a sizeable fraction do not have a father present. 
child's age group. This instrument is described at greater length in Part II below; the key point is that it purges the regression of unobserved individual-level characteristics as well as omitted variables such as economic conditions in a particular state and year. As expected, instrumenting causes our estimate to fall somewhat, yielding a marginal takeup rate of only $23 \%$.

One reason for these low takeup rates may be that a number of the children made eligible for Medicaid already had private health insurance. Among those who were ineligible for Medicaid in 1984 , but who were made eligible by the 1984 to 1992 rule changes, $38 \%$ were uninsured. Thus, the takeup rate among the otherwise uninsured may be as high as $60 \%(22.7 / 38)$. This takeup rate is an upper bound, however, since some of those who takeup Medicaid may have previously been privately insured, a point discussed at length by Cutler and Gruber (1995). ${ }^{11}$

Thus, while the Medicaid expansions doubled the fraction of children eligible for public insurance, the increase in the number of children covered was substantially lower. This result suggests that takeup may be an important barrier to the effectiveness of the Medicaid expansions. Still, the coverage response is not trivial, and does leave open the possibility that the expansions had significant effects on utilization and health.

\section{NHIS Data and Empirical Framework}

\section{NHIS Data}

The National Health Interview Survey (NHIS) interviews a large, nationally representative cross-section of American families each year. The baseline survey collects information about demographic characteristics, labor force attachment and family income. There are also a number

\footnotetext{
${ }^{11}$ Cutler and Gruber estimate a crowdout of children's private insurance by Medicaid of one-third of the Medicaid enrollment increase, so that if all those crowded out went onto Medicaid, the takeup rate among the otherwise uninsured would be $40 \%$.
} 
of questions about health status and utilization of medical care over the previous two weeks and the previous year. These data cover approximately 30,000 children per year, for a total 1984 to 1992 sample of over 225,000 .

Our first step is to assign eligibility to each child in the survey. This is more difficult in the NHIS than in the CPS for two reasons. First, family income is missing for a number of households. We impute missing income data by estimating yearly regressions of income on household characteristics in the CPS, and then using the regression coefficients to calculate income for NHIS households with similar characteristics in that year. ${ }^{12}$ Second, there is no information on the distribution of income across family members, or across income sources. This is problematic because, for example, some portion of earnings, but not other types of income, can be disregarded from total family income in determining AFDC eligibility. We applied these disregards to total income, under the assumption that most family income comes from earnings. ${ }^{13}$ These data problems do not seem to lead to any systematic measurement problems; the resulting annual eligibility rate in the NHIS is similar to the CPS in both the level and the time series trend. ${ }^{14}$

Our key variables in the NHIS are measures of utilization and health status. A potential problem with utilization measures is that they confound access and morbidity. For example, the

\footnotetext{
${ }^{12}$ For most of the missing observations, we know whether income was greater than or less than $\$ 20,000$, so we can impute income within those subsamples. These imputation regressions fit fairly well; the R-squareds for the yearly regressions estimated using all individuals average 0.45 . For those with incomes below $\$ 20,000$, the R-squareds average 0.32 ; while for those with incomes above $\$ 20,000$, the $\mathbf{R}$-squareds average $\mathbf{0 . 2 5}$. Note that the Census bureau uses a similar procedure to impute missing income data in the CPS.

${ }^{13}$ In the 1984 CPS, $75 \%$ of the average child's family income comes from his or her parents' earnings.

${ }^{14}$ In the years from 1984 to 1992 , the fraction of children eligible for Medicaid in the NHIS data was $14.5,17.2,19.1,19.2,18.5,19.3,25.2,27.5$, and $31.5 \%$. These numbers are very close to those shown in Table 1.
} 
Medicaid expansions may have increased access to hospitals, but at the same time they could have increased the use of preventive care, improving health status and reducing the demand for hospital care. One way to surmount this problem is to focus on utilization that is explicitly preventative, and therefore unaffected by morbidity. Pediatric guidelines recommend at least one doctor's visit per year for most children in our sample, so that the absence of a doctor's visit in the previous year is suggestive of a true access problem, regardless of underlying morbidity. ${ }^{15}$ This is therefore the measure we focus on in the analysis.

We also examine two other measures of contacts with the medical system: the probability of having had a doctor's visit in the past two weeks; and the probability of having had a hospitalization in the previous year. ${ }^{16}$ Both of these measures suffer from the bias noted above. Nevertheless, the former is useful in assessing the extent that Medicaid affects not only the probability of any contact, but also the frequency of contacts; the latter is useful in assessing whether Medicaid increases the utilization of providers other than physicians. Since the bias to these estimates from improved health status is obviously downwards, positive findings are suggestive of true utilization effects.

Concern over the utilization of the uninsured arises not only from their low number of medical contacts, but also from inefficiencies in their patterns of utilization. For example, Aday and Anderson (1984) report that among those with a regular source of care in $1982,87 \%$ of the

\footnotetext{
${ }^{15}$ More frequent visits are recommended for infants, and less frequent visits are recommended for older children. Efforts to produce separate results for children under age 2 were unsuccessful due to large confidence intervals.

${ }^{16}$ The NHIS includes telephone contacts as "visits". We exclude telephone contacts in our analysis since it is difficult to know how to interpret them. The results for number of visits in the last two weeks are somewhat stronger if we include telephone contacts.
} 
privately insured used a doctor's office as their regular source, and only $8 \%$ regularly used hospital outpatient departments or emergency rooms. Among the uninsured, however, only $74 \%$ regularly used a doctor's office, and $18 \%$ relied on hospitals for their regular source of care.

High hospital utilization rates among the uninsured are of concern for two reasons. First, hospital visits are more expensive. McDevitt and Dutton (1989) found that conditional on the illness, treating AFDC children in hospitals was $66 \%$ to $107 \%$ more expensive than treating them in physician's offices; Stuart (1990) et al. find that costs are 50\% higher in hospital settings, controlling for diagnosis. ${ }^{17}$ Second, care may be delivered more sporadically at settings other than the physician's office. As McDevitt and Dutton (1989) note, "it is widely accepted that having a regular source of care is an important component of quality care" (p. 44). They find that continuity of care, as measured by the percentage of visits to a single primary provider, is lower for those whose primary provider is a hospital rather than a physician; furthermore, those with less continuity of care have higher expenditures.

If a child had a visit in the last two weeks, the NHIS reports the site of care. We distinguish between three different sites: the physician's office; a hospital emergency room or outpatient clinic; and other sites, primarily private or public clinics. ${ }^{18}$ While it appears clear that care is delivered more efficiently in a physician's office than in a hospital, there is less of a consensus with respect

\footnotetext{
${ }^{17}$ It is difficult, of course, to completely control for the severity of illness, but these findings are suggestive of sizeable cost differences. Another problem is that costs to the Medicaid program do not represent true social costs; in particular, hospitals may shift overhead costs to price insensitive emergency room patients. In addition to providing higher priced care, hospital outpatient settings also perform more procedures and admit more patients for inpatient care (Stuart et al., 1990; McDevitt and Dutton, 1989).

${ }^{18}$ We include in the first category a small number of visits which took place in the patient's home. We also include a small number of visits to "doctor's offices in hospitals" in the "other" category since we wish to focus on the distinction between doctor's offices and hospital-based care in our analysis.
} 
to the relative efficiency of care at other sites. Gold (1981) and Gold and Greenlick (1981) found no differences in outpatient costs between hospital based and freestanding HMO clinics; the probability of inpatient admission was higher in the former setting, however, so that total costs were higher. Stuart et al. (1990) estimated that total payments per year for Maryland Medicaid patients were approximately twice as high at hospital outpatient departments than at clinics; clinic costs were approximately equal to office-based physician costs, although the probability of inpatient admission was higher. There is no evidence, however, about continuity of care in clinics vs. other sites. Thus, the efficiency implications of shifting visits to and from clinics is less clear than the implications of shifting to physicians and from hospitals.

As noted above, even if Medicaid increases the utilization of medical care, it may not improve health status. We use two types of parental reports about child health status in order to directly assess the health effects of Medicaid: whether the child is limited in any way in his or her daily activities; and whether the parent rates the child's health as "fair" or "poor", rather than "good" or "excellent". These indices are not objective measures of underlying health. In particular, they may capture two effects of increased contacts with the medical system: a "true" health effect; and a "reported" health effect that arises because contacts with medical practitioners may affect perceptions about the health status of the child. ${ }^{19}$

The direction of the bias in these two measures is unclear. If underlying child illness often goes undiagnosed by parents, then increased contacts with the medical system will lead to poorer assessments of child health, and the bias will be against finding that public insurance improves health. Alternatively, if parents tend to over-diagnose child illness, then increased contacts with

\footnotetext{
${ }^{19}$ For example, it is well known that better educated mothers report more illnesses among their children (Currie and Thomas, 1995; Thomas and Sindelar, 1991).
} 
physicians will reassure them and lead to improvements in parental reports of child health. In order to assess the importance of these biases, we will also examine the effects of the Medicaid expansions on a more objective aggregate measure of health status, child mortality.

The means of our NHIS data are presented in Table 3. We estimate that, across all years, $22 \%$ of the NHIS sample were eligible for Medicaid. Not surprisingly, Medicaid eligibles are more disadvantaged than the sample as a whole along a number of dimensions: they have less educated mothers and fathers; they are more likely to be minorities; they are more likely to live in a femaleheaded household; and they are substantially poorer.

Despite these disadvantages, they use medical care at almost exactly the same rate as noneligibles; in fact, they are hospitalized more frequently. This may reflect the fact that utilization confounds morbidity and access, as noted above. As Table 3 shows, Medicaid eligibles are in worse health according to parent-reported indicators of health status. Consistent with previous studies, we also see that Medicaid eligibles are less likely to have visited a doctor's office in the past two weeks, and more likely to have visited a hospital. They are also somewhat more likely to have used another site of care.

\section{Empirical Strategy}

We begin our analysis by estimating linear probability models of the effect of Medicaid eligibility on utilization and health status, of the form: ${ }^{20}$

$$
\mathrm{UTIL}_{i}=\alpha+\beta_{1} \mathrm{X}_{\mathrm{i}}+\beta_{2} \mathrm{ELIG}_{\mathrm{i}}+\beta_{3} \delta_{\mathrm{j}}+\beta_{4} T_{\mathrm{t}}+\epsilon_{\mathrm{i}}
$$

where UTIL $\mathrm{L}_{\mathrm{i}}$ is a measure of utilization, or health status, for individual $\mathrm{i}$

\footnotetext{
${ }^{20} \mathrm{We}$ use linear probability models for ease of computation and for consistency of our instrumental variables procedure. Heckman and MaCurdy (1985) show that this procedure produces consistent estimates.
} 
$\mathrm{X}$ is a set of control variables

ELIG is an indicator of the eligibility of individual i for Medicaid

$\delta_{\mathrm{j}}$ and $\tau_{\mathrm{i}}$ are a full set of state and year dummies, respectively

These OLS estimates, however, are subject to three sources of bias. The first is omitted variables bias. In all of our regressions we control for observable variables that directly determine eligibility for Medicaid. These include: income, the absence of a male head, the number of children in the family, and the age of the child (through single year age of dummies). ${ }^{21}$ We use the income categories reported by the NHIS to control for income; the omitted category are those with missing information on income. ${ }^{22}$ We also control for the child's gender, race, and ethnicity, whether he or she is the oldest child, the number of siblings, the education of the mother and (if present) the father, whether the mother or father was the respondent, the presence of other relatives, and whether the family lives in a central city or rural area. Even after conditioning on this detailed set of controls, however, persons who are eligible for Medicaid may have other characteristics that affect both their utilization and their health. For example, they may be more likely to live in areas with limited access to physicians.

A second problem is endogeneity bias. A sick child may cause lower parental income (if a parent is forced to leave work to care for the child, for example), leading to a spurious negative correlation between Medicaid eligibility and health. Finally, there may be substantial measurement error in our eligibility indicator, given the limitations of the NHIS income data.

Hence, in addition to the OLS estimates, we present instrumental variables estimates. Our aim is to abstract from characteristics of the child and/or family that may be correlated with both

\footnotetext{
${ }^{21}$ But note that we are unable to control for all of the possible interactions of these variables that might determine eligibility. This is a further argument for IV estimation.

${ }^{22}$ We imputed income for the purposes of determining Medicaid eligibility, as described above. However, we only use reported income categories in the regressions.
} 
eligibility and the dependent variables and to achieve identification using only legislative variation in Medicaid policy. One way to do this would be to instrument our imputed individual eligibility in the NHIS using the fraction of children in the same state, year, and age who are eligible, calculated from the CPS. This instrument would capture differences in Medicaid eligibility across states, years, and age groups, but would purge the regression of individual-level sources of variation in eligibility. ${ }^{23}$

This approach runs into two problems in practice, however. First the CPS is simply not large enough to permit reliable estimation of the fraction of children eligible in each state, year, and age category. Second, these estimates could be biased by the omission of characteristics of state, year, and age groups that are correlated with both eligibility and with utilization or health. For example, if infants in a given state and year were particularly poor they might have both higher eligibility levels and fewer doctor's visits, resulting in a downward bias in our estimates of the effects of eligibility on utilization.

Our strategy, therefore, is to use a "simulated instrument" that varies only with the state's legislative environment and not with its economic or demographic characteristics. In order to construct this instrument, we select a national random sample of 300 children of each age (0 to 14), in each year, and calculate the fraction of children in this sample who would be eligible for Medicaid given the rules in each state in that year. ${ }^{24}$ This measure can be thought of as a convenient

\footnotetext{
${ }^{23}$ This procedure is similar to instrumenting with a full set of state*year*age dummies in the NHIS data. However, as Bound et al. (1993) and Staiger and Stock (1993) note, such a strategy might suffer from finite sample bias even with our substantial sample size. Using the fraction eligible in each state, year, and age group from the CPS is akin to the two-sample solution proposed by Angrist and Krueger (1993).

${ }^{24}$ The sample size of 300 was chosen due to data and computational constraints. In order to assess the severity of potential problems due to sampling variability, we constructed our instrument twice, using two different random samples. The correlation between the two instruments was 0.97 .
} 
parameterization of legislative differences affecting children in different state, year, and age groups -

- a natural way to summarize the generosity of state Medicaid policy as it affects each group is in terms of the effect it would have on a given, nationally representative, population.

This instrumental variables strategy overcomes the econometric difficulties noted above. First, by using instruments that are arguably exogenous to utilization and health, we purge the model of endogeneity bias. Second, by using the fraction of children eligible in each child's state, year, and age group, we purge the model of any individual-level omitted variables correlated with both eligibility and outcomes. Third, to the extent that the measurement error in our instrument is uncorrelated with the measurement error in our individual eligibility measure, we also surmount the measurement error problem. ${ }^{25}$ Finally, by using a national random sample, we purge the model of state and year specific economic conditions that might be correlated with eligibility and with utilization or health; we also overcome the small sample problems that would arise in carrying out this IV strategy using the actual fraction eligible. This instrument is strongly correlated with individual eligibility; the first stage $\mathrm{F}$ statistic is approximately 10,000 . This is the instrument that was used in the two stage least squares (TSLS) results shown in Table 2.

The only remaining problem is that of omitted variables that are correlated with changes in state Medicaid policy, and also with differences in utilization or health. For example, rich states may have both more generous Medicaid policy and more medical utilization. Alternatively, expansions may have been phased in first for age groups with the highest exogenous growth in

25 If the measurement error stems mainly from random individual response error, then measurement error in our CPS instrument will be uncorrelated with that in our NHIS data, especially given the fact that the measure we calculate using the CPS is the average eligibility for a large group. However, if measurement error comes primarily from inaccuracies in the program we use to impute Medicaid eligibility, then we will have similar kinds of errors in individual eligibility measures calculated using either the NHIS or the CPS data. 
utilization over time. Any such omitted variable will invalidate our IV strategy, which treats the legislative environment for the state, year, and age group as a source of exogenous identification.

In order to control for these effects, we include a full set of dummy variables for states, years, and each single year of age. We also include interactions between each year of age and calendar year, and between each year of age and state. In principal, we could also include interactions between states and years in our models, since eligibility varies by age within states and years. ${ }^{26}$ When we include state and year interactions, the point estimates are similar to those presented below. However, including these variables removes much of the interesting legislative variation in the data, and our standard errors increase substantially.

\section{Medicaid Eligibility and Utilization}

Models of the utilization of medical care are presented in Table 4. The first three columns show the results from linear probability models estimated by OLS. The coefficients are multiplied by 100 and can therefore be interpreted as percentage point effects. Medicaid is found to significantly decrease (by 2.5 percentage points) the probability of going without a visit in the previous year, but to have no effect on having a visit in the past two weeks. ${ }^{27}$ Compared to the baseline probability of going without a visit, making a child eligible for Medicaid lowers the

\footnotetext{
${ }^{26}$ This would then be a true "difference-in-difference-in-difference" estimator, as employed by Gruber (1994) or Yelowitz (1994). The effects of all demographic and economic characteristics of states and years have already been purged by using our simulated instrument; interactions between states and years would capture omitted characteristics of a particular state and year that were correlated with both changes in the legislative environment, and utilization or health outcomes.

${ }^{27}$ Information about visits in the past two weeks and about hospitalizations were collected in special supplements to the main questionnaire and a great deal of effort was made in these supplements to avoid missing data. In contrast, the number of visits last year is from the main questionnaire and has more missing values, leading to a somewhat smaller sample size.
} 
probability of going without a visit by $13.1 \%$. Hospitalizations are also found to rise significantly; this represents a $19.3 \%$ rise relative to the baseline hospitalization rate.

As noted above, the OLS results may suffer from a number of biases. Two stage least squares estimates are shown in the next three columns of Table 4 , and suggest that in fact the OLS results are biased downwards: being made eligible for Medicaid is now associated with a 7.9 percentage point drop in the probability of going without a visit last year; which is over $40 \%$ of the baseline probability. The point estimate on the probability of having had a visit in the last two weeks becomes positive, although it is not statistically significant. Note that if this result was driven solely by the reduction in the probability of going without a visit last year, the implied increase in visits in the last two weeks would only be $0.3 \%$. Thus, the results in the first two columns suggest an increase in both access to care and use of care among those who already had some access. Finally, there is a very large and significant 4 percentage point rise in the probability of a hospitalization in the previous year. This coefficient implies that becoming eligible for Medicaid almost doubles the probability of being hospitalized.

The control variables suggest some interesting differences in utilization patterns across demographic groups. Blacks and hispanics use less medical care by all three measures; the differences are particularly large for blacks. There are also clear differences related to parental education. Children whose parents dropped out of high school are less likely to have had any visits in the past 12 months, and less likely to have had a visit in the past two weeks. Conversely, parents with some college education are more likely to take their children to the doctor. The dropout effects are similar for mothers and fathers, while the college effect is considerably stronger for mothers.

Utilization is higher for both first children and those in smaller families: the former may reflect parental diligence with respect to scheduling the first child's checkups that is relaxed for later 
children, while the latter may reflect the classic Becker (1981) child quality/quantity tradeoff. A surprising finding is that, conditional on household income, children in households with no male head have higher utilization levels. ${ }^{28}$ Having additional relatives in the house also reduces children's utilization of health care, and the effect is greater for male relatives than for female relatives. Finally, conditional on family structure, fathers report lower utilization rates than mothers, which may reflect inferior recall of the child's actual pattern of use.

The income patterns for visits suggest that, in keeping with the previous literature, visits are normal goods. On the other hand, hospitalizations appears to be an inferior good. Finally, physician utilization is slightly higher in inner cities, but much lower in rural areas; on the other hand, hospitalizations are much higher in rural areas. This last results is consistent with the findings of Goodman et al. (1994), who show that the supply of outpatient alternatives has a strong effect on pediatric hospitalization rates.

Thus, being made eligible for Medicaid has sizeable and significant effects on the utilization of medical care. This conclusion emerges both from OLS models, and (even more strongly) from two stage least squares models. These effects are quite large relative to other influences on the utilization of care. For example, the effect of Medicaid eligibility on the probability of going without a visit last year is roughly comparable to the effects of moving family income from the $\$ 10,000$ to $\$ 20,000$ range to the greater than $\$ 50,000$ range.

Site of Care

The effect of Medicaid eligibility on the probability that a child had a visit to one of three

${ }^{28}$ This result is consistent with evidence from many countries that ceteris parabis, resources in the hands of the mother have a greater impact on child well-being than resources in the hands of the father. See Thomas and Strauss (forthcoming) for a review of this literature. 
sites of care in the past two weeks is shown in Table $5 .^{29}$ Although we were unable to detect a statistically significant effect of eligibility on the probability of a visit in the past two weeks in Table 4, we find that there are significant effects on visits to specific sites. The probability of a visit to the doctor's office rises 4 percentage points, or almost one-half of the baseline probability; the probability of a visit to a hospital rises 2 percentage points, which is almost double the baseline probability; and the probability of a visit to another site falls 1.7 percentage points. These figures sum to roughly the $4 \%$ increase in visits in the last two weeks shown in Table 4 , and all are statistically significant at at least the $90 \%$ level of confidence.

It is difficult to draw strong conclusions about efficiency from these estimates because we do not know whether a change in the number of visits to a specific site reflects new visits, or a shifting of patients who would have obtained visits in any case to a new site of care. ${ }^{30}$ Nevertheless, we can state that the Medicaid expansions achieved their goal of increasing the number of patients visiting doctors' offices, either through visits that would not have occurred otherwise, or shifting from other sites of care. At the same time, there was also some increase in the utilization of emergency rooms and hospital clinics. Some of this rise in hospital visits may be coming from individuals who didn't receive care before; to the extent that the marginal benefits of the visit are

\footnotetext{
${ }^{29}$ An alternative estimation strategy would involve restricting the sample to those who had a visit in the past two weeks, and then examining the site of care. However, since the probability of having a visit is affected by Medicaid eligibility, restricting the sample in this way could lead to the inference that Medicaid was causing a behavioral shift in the site of care when in fact there was simply a compositional change in the pool of persons with a visit. An additional complication is that 839 children had more than one visit in the past two weeks, hence the sum of the visits to different sites may slightly exceed the total number of visits. We use linear probability models instead of multinomial logits here because the latter strategy was infeasible given the sample size, the number of covariates, and the endogeneity of eligibility.

${ }^{30}$ For example, it is possible that all new visits are to doctor's offices, while some patients shift from other sites to hospitals. Alternatively, some new visits may be to hospitals rather than to doctors' offices, while other patients shift from other sites to the doctor's office.
} 
greater than the costs of care, this is an improvement relative to the status quo ex ante.

It is possible, however, that at least some of the increased utilization of hospital sites is due to shifting from other sites of care. This could occur because hospitals are better equipped to assist Medicaid patients in claiming their benefits. Potential eligibles must complete lengthy and complex application forms, provide extensive documentation (such as birth certificates, pay stubs, and confirmation of child care costs), and attend several interviews with caseworkers. About one-third to one-half of all Medicaid applications are denied, and half of these denials are because the applicant did not complete all of the necessary steps. In response, many hospitals have established special offices, or contract with private companies, to assist Medicaid eligibles in completing these procedures (U.S. General Accounting Office, 1994). The non-trivial costs of providing these services may be beyond the means of smaller providers such as free-standing clinics. Hence, these clinics may suggest that patients who appear to be Medicaid-eligible seek care at the hospital.

Thus, to summarize, the Medicaid expansions appear to be increasing the number of visits to physicians' offices. However, there has also been an increase in the use of hospital-based services, which suggests that services may not be being rendered in the most efficient way possible.

\section{Part IV: Effects on Health}

\section{Parental Reports of Child Health}

In order to assess whether changes in utilization have had an effect in terms of improved child health, we next turn to subjective measures of health status from the NHIS. ${ }^{31}$ Table 6 reports

\footnotetext{
${ }^{31}$ The NHIS does collect information on more objective anthropometric measures (height and weight) for adults, but not for those under age 18. See Costa (1993) or Gruber and Kubik (1994) for applications of these data.
} 
the OLS and TSLS results for subjective health status. The OLS results indicate that Medicaid eligibility has no statistically significant effect on the probability that activity limits are reported, although it has a strong positive effect on the probability that the child is reported to be in poor or fair health.

The TSLS results for these health measures are reported in columns (3) and (4). The point estimates are both positive, indicating that increased Medicaid eligibility is associated with worse health, but neither is statistically significant. These results provide no evidence that the increased utilization associated with Medicaid eligibility has any positive effect on health. However, as discussed above, these subjective measures of child health are themselves suspect since they could be influenced by physician contacts regardless of the child's true health status. Thus, in order to more convincingly address the effects of eligibility on health, we turn to a more objective measure of child health.

\section{Child Mortality}

One important objective indicator of child health is child mortality, which is reported for each state and year for children aged 1 to 4 and 5 to 14 in the publication Vital Staristics. ${ }^{32}$ As our measure of eligibility we use the fraction eligible in each age group in each state and year, calculated from the Current Population Survey. We also recalculate our simulated instruments for these two age groups. Using these measures, we estimate TSLS models of deaths per 10,000 children as a function of the fraction eligible for Medicaid, instrumented using the simulated fraction eligible in each group. We control for a full set of age group, state, and year dummies. We also control for a full set of state*age effects, and age-specific trends. The regressions are weighted by the

\footnotetext{
${ }^{32}$ These data are only available through 1991.
} 
population in each state/year/age cell. ${ }^{33}$

These TSLS estimates are presented in the first column of Table 7. We find a significant negative effect of increased Medicaid eligibility on the child mortality rate. The coefficient implies that for every 10 percentage point increase in the fraction of children eligible for Medicaid, mortality drops by 0.098 percentage points; this is $3 \%$ percent of the baseline mortality rate in the sample. Thus, the 15.1 percentage point rise in eligibility between 1984 and 1992 is estimated to have decreased child mortality by $4.5 \%$. In contrast to the self-reported measures, these objective data suggest that the Medicaid eligibility expansions had significant effects on child health.

One means of interpreting our finding is to calculate the cost to Medicaid per child life saved. The average cost of Medicaid per year per low income child on the program is $\$ 902$ (Congressional Research Service, 1993); this estimate excludes the disabled, who cost substantially more. According to the instrumental variables takeup results in Part I, making $10 \%$ more children eligible for Medicaid raises the number of children covered by the program by $2.27 \%$; in 1992, this would have been 1,293,194 children. The cost of covering these children would be $\$ 1.17$ billion. The regression results imply that 556 lives would be saved (using the coefficient of -0.976 in the first column). This is a cost per life saved of roughly $\$ 2.1$ million.

This estimate is lower than recent compensating differentials estimates of the value of a life; Viscusi (1993) summarizes these studies and concludes that the most reliable range of estimates is

${ }^{33}$ Interactions between age group and calendar year were not statistically significant in the mortality model, so for efficiency reasons we replaced them with age-specific trends (which are also insignificant). The results are similar, but weaker, when the full set of year of age and calendar year interactions are included. In our discussion above, we also noted that a problem with using actual eligibility in the CPS is small cell sizes by age/state/year. This is less of a problem in the current context, since we are using two broad age groups. Also, our instrumental variables strategy will remove any measurement error bias arising from the fact that some of our average eligibility measures are computed using small cell sizes. Unweighted regressions yield quite similar results. 
$\$ 4$ to 7 million per life saved. It is also lower than the cost per life saved from a number of current government regulatory policies, according to Breyer (1993). ${ }^{34}$ It is, however, somewhat higher than the cost of saving a life through Medicaid expansions to pregnant women estimated in Currie and Gruber (1994).

Moreover, this estimate is likely to be an upper bound, for several reasons. First, the cost for the marginal child brought onto the Medicaid program through the expansions of the late 1980s is likely to be lower than the average cost of a low income child on Medicaid, since the very lowest income children (who are likely to be in the poorest health) were already eligible under the AFDC, Medically Needy, or Ribicoff child programs. ${ }^{35} \quad$ Second, this calculation ignores incremental benefits to health that arise from Medicaid coverage but fall short of saving a child's life. Third, we do not consider the savings to both the public and private sectors from reductions in the uncompensated care that is currently being delivered to uninsured children. Finally, we ignore any other savings to the private sector that accrue from individuals dropping private insurance to takeup Medicaid. ${ }^{36}$

\footnotetext{
${ }^{34}$ On the other hand, it is difficult to know how to value a child's life relative to the adult lives valued in Viscusi and Breyer's work.

${ }^{35}$ In fact, in the NHIS, the parentally-reported health of those children made eligible under the expansions is better than that of children who were eligible under the old program rules. For those eligible under AFDC or the Medically Needy or Ribicoff child programs, 5.5\% report fair/poor health and 6.7\% report an activity limit. For those made eligible under the 1987 to 1992 income expansions, 3.2\% report fair/poor health and 3.6\% report an activity limit.

${ }^{36}$ At the same time, however, we do not consider the increased deadweight loss from government revenue raised to finance these Medicaid expenditures.
} 


\section{Part V: Exploring Equalization Efrects of the Expansions}

Racial Differences in Utilization

One goal of many advocates of universal coverage is the equalization of access to medical care. Thus, it is of interest to assess whether, conditional on its mean effects, Medicaid policy equalizes the utilization of care. It is not obvious, however, that increasing insurance eligibility will equalize utilization. A number of the problems noted in the introduction, such as the alleged segregation of Medicaid providers from the population in greatest need, suggest that increasing Medicaid eligibility could actually make utilization even more unequal by increasing the demands on a limited number of suppliers of care. Furthermore, important disparities in utilization and health remain even in countries with universal insurance coverage (c.f. The Black Report in Townsend et al. 1988).

In the United States, racial differences in the utilization of health care are particularly glaring -- for example, black children are $27 \%$ more likely than other children to go without a visit in the previous year. In order to investigate whether increases in eligibility led to decreases in racial utilization gaps, we re-estimated our models separately for black and non-black ("white") children. ${ }^{37}$ The results are reported in Table 8. Here, the simulated eligibility measure varies not only by state, year, and child age, but by race as well. All models are estimated using TSLS. Within each racial group, the identifying assumptions for the estimation are the same as those discussed above.

The results suggest that Medicaid eligibility does reduce racial disparities in the number of visits,. For example, the estimates suggest that eligibility reduces the probability of no visits by 11.5

\footnotetext{
${ }^{37}$ Even if the coefficient for each racial group were the same, there would be some equalization from the expansions, as blacks are poorer and therefore more likely to be affected by Medicaid expansions. We are asking whether, for a given person, the effects are stronger for blacks than for whites.
} 
percentage points among blacks compared to only 5.9 percentage points among whites. The standard errors are large and these estimates are not significantly different from each other. Nevertheless, taken at face value, these point estimates suggest that if even one-half of all children were made eligible for Medicaid there would be no racial inequity in the probability of having at least one visit in the previous year. ${ }^{38}$ The results for the probability of a visit in the past two weeks are even more striking. There is a very large and significant effect on blacks, which is roughly as large as the baseline probability. At the same time, there is only a small and insignificant effect for whites. For hospitalization, the effect is approximately equal across the two groups.

On the other hand, the next panel suggests that increases in Medicaid eligibility exacerbate disparities in the site of care. While the point estimates indicate that visits to all three sites of care increased among blacks, only the effect on hospital sites is statistically significant. The coefficient is sizeable, suggesting that Medicaid eligibility more than triples the probability that blacks have a visit at a hospital over a 2 week period. For whites, the pattern is similar to that in Table 5 , with rising visits at both doctors' offices and hospitals, and falling visits at other sites.

On the whole, these estimates suggest that while newly eligible blacks experience a greater increase in the number of visits than newly eligible whites, blacks are more likely than whites to receive their care in hospital settings. This result may reflect the proximity of many inner-city blacks to urban hospitals.

${ }^{38}$ Although universal health insurance coverage does not eliminate all disparities in adult health. it may greatly reduce disparities in the utilization of care among children. For example, in their comparative study of health care for young children, Williams and Miller (1992) state that it is "virtually unheard of" for children in European countries to lack a regular source of care. However. not all of this closing of the gap can be attributed to the extension of health insurance coverage. Most European countries also have aggressive public health programs that either bring preventive care to the child, or offer strong incentives for parents to bring children in to get preventive care. 


\section{Utilization Differences by Parental Education}

The discussion above suggested that getting through the application process may be a significant problem for many Medicaid eligibles. Better educated parents may be more able to deal with the process. On the other hand, less educated parents are more likely to have had previous experience with the welfare system, and they are less likely to be privately insured. Hence, it is interesting to see whether there are differential effects of eligibility by parental education levels.

In order to examine this question, we split our sample by whether or not the child's mother is a high school dropout. ${ }^{39}$ The results are reported at the bottom of Table 8 . In terms of the number of visits, the most striking result is that eligibility has a much greater impact on the probability that a child received any visits in the past year if the mother is a high school dropout. This results parallels our racial findings of reduced disparities in the utilization of care as Medicaid eligibility rises. It is also interesting to note that the probability of hospitalization rises by approximately equal amounts for both educational groups as well as for both racial groups. This finding suggests that decisions about the hospitalization of these children have more to do with the patient's insurance status than with the educational or racial characteristics of the families.

Turning to the site of visits, we once again see that the disadvantaged group (dropouts) has a significant increase in the number of visits to hospital clinics and emergency rooms, without any significant change in the number of visits to doctor's offices. On the other hand, the advantaged group (non-dropouts) experiences an increase in the number of visits to doctor's offices that is significant at the $90 \%$ level of confidence. Hence, more educated parents appear to be better able to translate Medicaid eligibility into visits to doctor's offices than parents with less education. Once

\footnotetext{
${ }^{39}$ As with the racial results, our instrument is calculated separately for each age/education/state/year group.
} 
again, the results suggest that increases in Medicaid eligibility reduce disparities in overall utilization of care, while exacerbating disparities in the site of care.

\section{Racial Mortality Differences}

Once again, disparities in utilization are most interesting if they can be related to differences in health status. Since the mortality data used above are reported by race, we are able to investigate the effect of the expansions on white and black mortality separately. These results are reported in Table 7.40 The Vital Statistics indicate that black children are $63 \%$ more likely to die then white children. But our point estimates indicate that Medicaid eligibility increases are associated with a dramatic reduction in that disparity. For whites, Medicaid has a quantitatively small and statistically insignificant effect on mortality. But for blacks the result is quite large, although it is only significant at the $15 \%$ level. Given the large standard errors, we cannot say whether the effects are truly larger for blacks than for whites, but given the effects of eligibility on utilization, the results are suggestive.

This large difference in the estimated coefficients is reflected in the estimated cost per life saved reported in the next row of the table." For whites the cost per life saved is over $\$ 6$ million

\footnotetext{
${ }^{40}$ The empirical strategy is the same as that described above: we calculate actual eligibility by age/race/state/year group in the CPS, and then instrument this with simulated eligibility by age/race/state/year group. The regressions are weighted by the population of children in each age/race/state/year cell. There are some empty age/state/year cells for black children in the CPS, so that the black sample is only $90 \%$ as large as the white sample. However, the lost observations are not influential on the analysis; if we run the reduced form regression (mortality on simulated eligibility, which can be calculated for all 816 age/state/year cells) both with and without the observations that are missing actual eligibility, the answers are quite similar.

${ }^{41}$ These calculations use race-specific takeup rate regressions to calibrate the program cost of the expansions. The TSLS takeup coefficient for whites is 0.237 ; for blacks it is 0.256 ; both are highly significant.
} 
but for blacks the cost is only $\mathbf{\$ 1 . 4}$ million. These figures suggest large equalizing effects of Medicaid expansions.

\section{Part VI: Conclusions}

Expansion of health insurance for children remains a popular public policy, despite the controversy about health care reform. The strong support for insuring children reflects the assumption that lack of insurance is responsible for the poor health of American children. Furthermore, there is some public support for the concept that health care is a basic human right, and that the sizeable disparities in the utilization of care among children violate this right (Castelle, 1990; U.S. National Committee on the International Year of the Child, 1980). Unfortunately, little is known about the utilization and health effects of extending eligibility for public health insurance to previously ineligible groups of children. The goal of this paper has been to address these questions while suggesting a new way of surmounting the methodological problems involved in doing so.

Our attempt to solve these problems centers around our use of recent expansions of Medicaid eligibility as a source of identifying variation in models of utilization and health. The resulting instrumental variables models yield a number of interesting findings. In particular, we find that making a child eligible for Medicaid lowers the probability that he or she goes without a doctor's visit during the year by $40 \%$, and raises by almost $50 \%$ in the probability that a child went to a physician's office in the past two weeks. At the same time, there is a substantial increase in the probability that a child visits a hospital, suggesting some inefficiency in the way that care is delivered to Medicaid enrollees. While Medicaid eligibility does not have significant effects on parentallyassessed health, it is associated with a significant decline in child mortality. Finally, Medicaid 
eligibility reduces race and education-based disparities in the number of visits, and is associated with a reduction in racial differences in mortality rates, although it may actually exacerbate existing disparities in the site of care.

This research raises a number of interesting questions that are crucial to the understanding of the role of public insurance. First, how might the impact of public insurance differ if takeup among eligibles was increased? Are eligibles who do not take up coverage less needy, or do they simply face larger informational and other barriers? Second, how can public policies deliver care to the publicly insured more efficiently? Our results are consistent with previous research which suggests that Medicaid eligibility does not guarantee access to physician's offices. Currie, Gruber, and Fischer (1995) find that increases in the fees paid to obstetrician/gynecologists by the Medicaid program were associated with declines in infant mortality, which suggests that supply side policies can have important effects on access to physicians and on outcomes. How might other supply side policies impact the efficiency of care and outcomes? Finally, what are the health benefits of public insurance beyond the effect on child mortality? In future work, we hope to move beyond this relatively crude measure of health to investigate the effects of Medicaid on other, more detailed, indicators of objective health status. The availability of micro-data on objective health outcomes would be an invaluable tool for such future assessments of the implications of public insurance for health status. 


\section{References}

Angrist, Joshua D. and Alan B. Kreuger (1993). "Split Sample Instrumental Variables." Mimeo, Princeton University.

Becker, Gary (1981). A Treatise on the Family. Cambridge: Harvard University Press.

A. Bindman et al., "A Public Hospital Closes: Impact on Patients' Access to Care and Health Status," Joumal of the American Medical Association 264 (December 12, 1990), 2899-2904.

Blank, Rebecca, and Patricia Ruggles. "When Do Women Use AFDC and Food Stamps?: The Dynamics of Eligibility vs. Participation," NBER Working Paper \#4429, 1993.

Blank, Rebecca, and David Card. "Recent Trends in Insured and Uninsured Employment: Is there and Explanation?," Ouarterly Journal of Economics, 106, 1157-1190.

Bloom, Barbara. "Health Insurance and Medical Care," Advance Data from Vital and Health Statistics of the National Center for Health Statistics, \#188, Washington D.C.: Public Health Service, October 1, 1990.

Bound, John, David A. Jaeger and Regina M. Baker (1993). "The Cure Can Be Worse Than the Disease: A Cautionary Tale Regarding Instrumental Variables." Mimeo, University of Michigan.

Castelle, Kay. In the Child's Best Interest: A Primer on the UN Convention on the Right of the Child, New York: Defence for Children International, 1990.

Congressional Research Service (1988, 1993). Medicaid Source Book: Background Data and Analysis. Washington, D.C.: Government Printing Office.

Costa, Dora L. (1994). "Working With Pain: Disability and Labor Force Participation, 1900-1991 ". Mimeo, MIT.

Currie, Janet and Jonathan Gruber (1994). "Saving Babies: The Efficacy and Cost of Recent Expansions of Medicaid Eligibility for Pregnant Women," NBER Working Paper \#4644, February 1994.

Currie, Janet, Jonathan Gruber, and Michael Fischer (1995). "Physician Payments and Infant Health: Effect of Increases in Medicaid Reimbursements," American Economic Review, May. 1995

Currie, Janet and Duncan Thomas. "Medical Care for Children: Public Insurance, Private Insurance. and Racial Differences in Utilization," Journal of Human Resources, Winter, 1995.

Cutler, David, and Jonathan Gruber (1995). "Does Public Insurance Crowd Out Private Insurance?". Mimeo, NBER. 
Fossett, James W., and John A. Peterson (1989). "Physician Supply and Medicaid Participation: The Causes of Market Failure," Medical Care, 27:386-396.

Fossett, James W., Janet D. Perloff, Phillip R. Kletke, and John A. Peterson (1992). "Medicaid and Access to Child Health Care in Chicago," Journal of Health Politics. Policy and Law, 17:273-298.

Gold, M. (1981). "Effects of Hospital-Based Primary Care Setting on Internists' Treatment of Primary Care Episodes," Health Services Research, 16, 383-405.

Gold, M., and M. Greenlick (1981). "Effects of Hospital-Based Primary Care Setting on Internists' Use of Inpatient Hospital Resources," Medical Care, 19, 160-171.

Goodman, David, Elliot Fisher, Alan Gittelsohn, Chiang-Hua Chang, and Craig Fleming. "Why are Children Hospitalized? The Role of Non-Clinical Factors in Pediatric Hospitalizations", in Pediatrics, 93 \#6: 896-902, June 1994.

Gruber, Jonathan and Jeffrey D. Kubik (1994). "Disability Insurance Rejection Rates and the Labor Supply of Older Workers." Mimeo, MIT.

Heckman, James and Thomas MaCurdy. "A simultaneous Equations Linear Probability Model", in The Canadian Journal of Economics, February 1985, 28-37.

Hoynes, Hilary (1993). "Welfare Transfers in Two Parent Families: Labor Supply

a $\quad \mathbf{n}$ d Welfare Participation Under AFDC-UP", NBER Working Paper $\$ 4407$.

Kasper, Judith. "Health Status and Utilization: Differences by Medicaid Coverage and Income," Health Care Financine Review, 7:1-17, 1986.

Kemper, Kathi. "Medically Inappropriate Hospital Use in a Pediatric Population", The New England Journal of Medicine, 318 \#16: 1033-1037, April 21, 1988.

Kozak, L.J. and E. McCarthy. "Hospital Use by Children in the United States and Canada," Vital and Health Statistics, Series 5 \# (PHS)84-1477, Washington D.C.: Public Health Service, August 1984.

Lurie, N., et al. (1984). "Termination from Medi-Cal: Does it Affect Health?," New England Journal of Medicine 311, 480-484.

McDevitt, Roland D., and Benson Dutton (1989). "Expenditures for Ambulatory Episodes of Care: The Michigan Medicaid Experience," Health Care Financing Review, 11(2):43-55.

Moffitt, Robert (1992). "Incentive Effects of the U.S. Welfare System: A Review," Journal of Economic Literature, 30, 1-61.

Mullahy, John. "Medicaid and the Timing of Preventive Health Care for Young Children," mimeo, 
Trinity College, July 1994.

National Governor's Association (various years). Catalog of State Medicaid Program Changes.

Washington, D.C.: NGA.

Newhouse, Joseph (1993). Free for All? Lessons from the RAND Health Insurance Experiment. Santa Monica, CA: Rand.

Short, Pamela and Doris Lefkowitz. "Encouraging Preventive Services for Low-Income Children: The Effect of Expanding Medicaid", Medical Care, 30 "9:766-780, Sept. 1992.

Staiger, Douglas and James H. Stock (1993). "Asymptotics for Instrumental Variables Regressions with Weakly Correlated Instruments." Mimeo, Kennedy School of Government, Harvard University.

Stuart, Mary, Donald Steinwachs, Jennifer Harlow, and Michael Fox (1990). "Ambulatory Practice Variation in Maryland: Implications for Medicaid Cost Management, "Health Care Financing Review, Annual Supplement, 57-67.

Thomas, Duncan and John Strauss. "Human Resources: Empirical Modeling of Household and Family Decisions," Handbook of Development Economics, T.N. Srinivasan and Jere Behrman (eds)., North Holland: Amsterdam, forthcoming.

Thomas, Duncan and Jody Sindelar. "Measurement of Child Health: Maternal Response Bias," Yale Economics Growth Center Discussion Paper \#633, June 1991.

Townsend, Peter, Nick Davidson, and Margaret Whitehead. Inequalities in Health, London: Penguin, 1988.

U.S. General Accounting Office, Health Care Reform: Potential Difficulties in Determining Eligibility for Low-Income People. GAO/HEHS-94-176, July 1994.

U.S. National Commission on the International Year of the Child. Report to the President, Washington D.C.: GPO, 1980.

Valdez, Burciega. The Effects of Cost Sharine on the Health of Children, Publ. No. \$-3270, Santa Monica: RAND, 1986.

Viscusi, Kip (1992). Fatal Tradeoffs. New York: Oxford University Press.

Williams, Bret and Arden Miller. "Preventive Health Care for Young Children: Findings from a 10Country Study and Directions for United States Policy", Pediatrics, 89 \#5: 983-998, May 1992.

Yelowitz, Aaron S. (1994). "The Medicaid Notch, Labor Supply and Welfare Participation: Evidence from Eligibility Expansions." Mimeo, MIT. 


\section{Appendix A : Simulating Medicaid Eligibility}

In this appendix, we describe our procedure for imputing the Medicaid eligibility of individuals in the CPS and NHIS. Our source for information on state Medicaid options is National Governors Association (various years) and Congressional Research Service $(1988,1993)$.

\section{a) Eligibility for AFDC}

In order to qualify for AFDC, the child's family must satisfy three tests: 1) gross income must not exceed a given multiple of the state need's standard ${ }^{42}$, 2) the gross income less certain "disregards" must be below the state needs standard, and 3) the gross income less the disregards, less a portion of their earnings, must be below the state's payment standard.

The disregards can be computed as follows. Beginning in October 1981, the allowance for work and child care expenses was $\$ 75$ per month for work expenses and a maximum of $\$ 160$ per child for child care costs. These allowances were not changed until the Family Support Act of 1988, which raised the allowances to $\$ 90$ for work expenses and $\$ 175$ per child for child care expenses, effective October 1, 1989. In addition, a portion of earned income was disregarded. In 1984, women were allowed to keep $\$ 30$ plus $1 / 3$ of earned income for four months. Hence, we assumed that women could keep $\$ 120+1 / 9$ of their earnings for the year. From 1985 onwards, individuals who would have become ineligible for AFDC (and hence for Medicaid) after the 4 months were allowed to remain eligible for Medicaid for an additional 9 to 15 months depending on the state. We modelled this by assuming that for Medicaid eligibility purposes, women were allowed to keep the full $\$ 30$ and $1 / 3$. Our aim was to consistently model the maximum amount that a person could have received while remaining eligible for Medicaid coverage under AFDC. Finally, AFDC rules until October, 1984 mandated that women be assumed to be using the Earned Income Tax Credit, regardless of whether they actually were doing so. We follow this assumption in our eligibility calculation for 1984 only.

One difficulty in implementing these rules in the NHIS is that the disregards apply only to earned income and we cannot distinguish between earned income and other income. We therefore assumed that all household income was earned. This assumption yielded AFDC eligibility findings in the NHIS that were similar to those from the CPS, where we have data on individual earnings by source.

The second set of rules that must be evaluated to see if a child is eligible for AFDC are rules relating to family structure. Eligibility under the traditional program requires that the child reside in a female-headed household. However, children in two-parent households may still have been eligible under the AFDC-UP program. Eligibility for AFDC-UP conditions on both current employment status and work history. Data on AFDC-UP regulations are from Hoynes (1993). In addition, some states covered families with Medicaid if they had an unemployed head, even if there was no AFDC coverage; these states are identified in National Governor's Association (various years).

\footnotetext{
${ }^{42}$ In 1984 this multiple was 1.5. From 1985 onwards, the multiple was 1.85 .
} 
Lacking longitudinal data on work histories, we assume in the CPS that families are eligible if the state has a program, and the spouse had worked less than $\mathbf{4 0}$ weeks in the previous year. In the NHIS we are only able to determine whether or not the spouse is currently unemployed. Hence, our estimates of the AFDC-UP caseload is biased upwards because we cannot determine that those who are unemployed have been attached to the labor force long enough to qualify for AFDC-UP. Still, our estimates of the size of the AFDC-UP caseload appear to be reasonable as we find that about 1 in 20 AFDC eligibles qualify through that program, matching the ratio reported in administrative data.

\section{b) Eligibility under state Medically Needy programs.}

In some states, children in families with incomes too high for AFDC could qualify for Medicaid under state Medically Needy programs. Income thresholds for these programs could be set no higher than $133 \%$ of the state's needs standard for AFDC. Families could "spend down" to these thresholds by subtracting their medical expenditures from their gross incomes (less disregards) - if they did so, then Medicaid would pay the remainder of their medical expenses. In order to qualify, however, families must have high medical expenditures for several consecutive months (the "spend down period"). We have no way of determining which families have had such high medical spending in the CPS, and we are reluctant to do so in the NHIS since eligibility would then be a direct function of utilization and health. As an approximation, we set the eligibility thresholds to the Medically Needy levels in states with this program. Data on Medically Needy coverage and thresholds is from National Governors Association (various years).

\section{c) Eligibility for Ribicoff children.}

Ribicoff children are those who would qualify for AFDC given income criteria alone, but who do not qualify for reasons of family structure. States may or may not choose to cover children under this optional program. In states that do cover them, we ignore the family structure requirements and screen only on income. Some states cover selected groups of children (such as only those in two parent families, or only those in institutions). However, we were unable to obtain precise information on the groups of children covered. Hence, we count the state as a "Ribicoff state" only if it covers all categories of children, as reported by the National Governors Association. We have also tried calling all of the states to obtain information about their Ribicoff children program; the resulting information appeared unreliable, since almost every state said that they had a program whereas secondary sources report that coverage is much more selective. Using the state self-reported coverage yielded similar results to those reported in the paper.

\section{d) Eligibility under the Medicaid Expansions.}

See Appendix Table 1 for a summary of the relevant legislation. If family income and the child's age were less than the cutoffs, we assumed that the child was eligible. One important question is whether states apply AFDC disregards when computing a family's eligibility for the expansions. Discussions with several state and federal Medicaid administrators suggested that such disregards were generally applied, so we used them in our eligibility calculations. Calculating eligibility without the disregards yielded a significantly smaller effect of the expansions, but the regression results were quite similar. 


\section{Appendix Table 1: The Medicaid Expansions}

Deficit Reconciliation Act, 1984: Effective October 1, 1984. Required states to extend Medicaid coverage to children born after September 30,1983, if those children lived in families that were income-eligible for AFDC.

Omnibus Budget Reconciliation Act, 1986: Effective April 1, 1987. Permitted states to extend Medicaid coverage to children in families with incomes below the federal poverty level. Beginning in fiscal year 1988, states could increase the age cutoff by one year each year, until all children under age five were covered.

Omnibus Budget Reconciliation Act, 1987: Effective July 1, 1988. Permitted states to cover children under age 2, 3, 4, or 5, who were born after September 30, 1983. Effective October 1, 1988, states could expand coverage to children under age 8 born after September 30, 1983. Allows states to extend Medicaid eligibility to infants up to one year of age in families with incomes up to $185 \%$ of the federal poverty level. States were required to cover children through age 5 in fiscal year 1989, and through age 6 in fiscal year 1990, if the families met AFDC income standards.

Medicare Catastrophic Coverage Act, 1988: Effective July 1, 1989, states were required to cover infants up to age on in families with incomes less than $75 \%$ of the federal poverty level. Effective July 1,1990 , the income threshold was raised to $100 \%$ of poverty.

Family Support Act, 1988: Effective April 1, 1990. States were required to continue Medicaid coverage for 12 months among families who had received AFDC in three of the previous six months, but who had become ineligible because of earnings.

Omnibus Budget Reconciliation Act, 1989: Effective April 1, 1990. Required states to extend Medicaid eligibility to children up to age 6 with family incomes up to $133 \%$ of the federal poverty line.

Omnibus Budget Reconciliation Act, 1990: Effective July 1, 1991. States were required to cover all children under age 19 who were born after September 30, 1983 and whose family incomes were below $100 \%$ of the Federal poverty level. 
Appeadk Table 2

Age and Income Elizibility Thresbolds for Expanded Medicaid Coverage

\begin{tabular}{|c|c|c|c|c|}
\hline $\begin{array}{l}\text { State } \\
\text { Alabama }\end{array}$ & Age 1/88 & Income 1/88" & $\begin{array}{c}\text { Age } 12 / 89 \\
1\end{array}$ & $\begin{array}{c}\text { Income 12/89 } \\
100\end{array}$ \\
\hline Alaska & & & 2 & 100 \\
\hline Arizone & 2 & 200 & 6 & 100 \\
\hline Arkansas & 2 & 75 & 6 & 100 \\
\hline Califomia & & & 5 & 100 \\
\hline Colorado & & & 1 & 75 \\
\hline Connecticut & 1 & 100 & 1 & 185 \\
\hline Delaware & 1 & 100 & 3 & 100 \\
\hline D.C. & 2 & 100 & 2 & 100 \\
\hline Florida & 2 & 100 & 6 & 100 \\
\hline Georgia & & & 3 & 100 \\
\hline Hawaii & & & 4 & 100 \\
\hline Idaho & & & 1 & 75 \\
\hline Illinois & & & 1 & 100 \\
\hline Indiana & & & 3 & 100 \\
\hline lowa & & & 6 & 100 \\
\hline Kansas & & & 5 & 100 \\
\hline Kentucky & 2 & 100 & 2 & 100 \\
\hline Louisiana & & & 6 & 100 \\
\hline Maine & & & 5 & 100 \\
\hline Maryland & 2 & 100 & 2 & 100 \\
\hline Massachusetts & 2 & 100 & 5 & 100 \\
\hline Michigan & 2 & 100 & 3 & 100 \\
\hline Minnesota & & & 8 & 100 \\
\hline Mississippi & 2 & 100 & 5 & 100 \\
\hline Missouri & 2 & 100 & 3 & 100 \\
\hline Montana & & & 1 & 100 \\
\hline Nebraska & & & 5 & 100 \\
\hline Nevada & & & 6 & 75 \\
\hline New Hampahire & & & 1 & 100 \\
\hline New Jersey & 2 & 100 & 2 & 100 \\
\hline New Mexico & 2 & 100 & 3 & 100 \\
\hline New York & & & 1 & 185 \\
\hline North Carolina & 2 & 100 & 7 & 100 \\
\hline North Dakota & & & 1 & 75 \\
\hline Ohio & 1 & 100 & 1 & 100 \\
\hline Oklahoma & 2 & 100 & 2 & 100 \\
\hline Oregon & 2 & 85 & 3 & 85 \\
\hline Pennaylvania & 2 & 100 & 6 & 100 \\
\hline Rhode Island & 2 & 100 & 6 & 100 \\
\hline South Carolina & 1 & 100 & 6 & 100 \\
\hline South Dakota & & & 1 & 100 \\
\hline Tennessee & 2 & 100 & 6 & 100 \\
\hline Texas & & & 4 & 100 \\
\hline Utah & 2 & 100 & 1 & 100 \\
\hline Vermont ${ }^{-}$ & 2 & 100 & 6 & 225 \\
\hline Virginis & & & 1 & 100 \\
\hline Washington & 2 & 90 & 8 & 100 \\
\hline Weat Virginia & 2 & 100 & 6 & 100 \\
\hline Wisconsin & & & 1 & 120 \\
\hline Wyoming & & & 1 & 100 \\
\hline
\end{tabular}

Notes: From Yelowitz (1994). ${ }^{*}=$ Income is given as a percent of the federal poverty line.

- = Vermont obtained a waiver in order to set the income limit at 225\%. 


\begin{tabular}{|cccc|cccc||}
\hline \multicolumn{7}{|c|}{ Appendix Table 3: Eligibility by State } \\
\hline \multicolumn{7}{|c|}{ Actual Economic Conditions } & \multicolumn{4}{|c||}{ Fixed Economic Conditions } \\
\hline State & 1984 & 1992 & Diff & State & 1984 & 1992 & Diff \\
\hline AL & 0.111 & 0.252 & 0.141 & AL & 0.111 & 0.348 & 0.237 \\
AK & 0.179 & 0.208 & 0.029 & AK & 0.179 & 0.213 & 0.035 \\
AZ & 0.066 & 0.369 & 0.303 & AZ & 0.066 & 0.394 & 0.328 \\
AR & 0.163 & 0.292 & 0.129 & AR & 0.163 & 0.356 & 0.193 \\
CA & 0.294 & 0.406 & 0.112 & CA & 0.294 & 0.343 & 0.050 \\
CO & 0.073 & 0.211 & 0.138 & CO & 0.073 & 0.191 & 0.118 \\
CT & 0.122 & 0.273 & 0.151 & CT & 0.122 & 0.170 & 0.048 \\
DE & 0.133 & 0.198 & 0.065 & DE & 0.133 & 0.277 & 0.144 \\
DC & 0.427 & 0.474 & 0.047 & DC & 0.427 & 0.523 & 0.096 \\
FL & 0.116 & 0.337 & 0.221 & FL & 0.116 & 0.311 & 0.196 \\
GA & 0.120 & 0.327 & 0.207 & GA & 0.120 & 0.314 & 0.195 \\
HI & 0.126 & 0.278 & 0.152 & HI & 0.126 & 0.287 & 0.161 \\
ID & 0.065 & 0.292 & 0.227 & ID & 0.065 & 0.299 & 0.234 \\
IL & 0.204 & 0.287 & 0.083 & IL & 0.204 & 0.291 & 0.087 \\
IN & 0.089 & 0.272 & 0.183 & IN & 0.089 & 0.243 & 0.154 \\
IA & 0.206 & 0.266 & 0.060 & IA & 0.206 & 0.300 & 0.095 \\
KS & 0.065 & 0.190 & 0.125 & KS & 0.065 & 0.181 & 0.116 \\
KY & 0.117 & 0.330 & 0.213 & KY & 0.117 & 0.298 & 0.181 \\
LA & 0.106 & 0.357 & 0.251 & LA & 0.106 & 0.329 & 0.223 \\
ME & 0.165 & 0.335 & 0.170 & ME & 0.165 & 0.338 & 0.172 \\
MD & 0.114 & 0.317 & 0.203 & MD & 0.114 & 0.185 & 0.072 \\
MA & 0.152 & 0.259 & 0.107 & MA & 0.152 & 0.242 & 0.090 \\
MI & 0.261 & 0.283 & 0.022 & MI & 0.261 & 0.334 & 0.072 \\
MN & 0.143 & 0.325 & 0.182 & MN & 0.143 & 0.284 & 0.141 \\
MS & 0.154 & 0.380 & 0.226 & MS & 0.154 & 0.390 & 0.237 \\
MO & 0.116 & 0.329 & 0.213 & MO & 0.116 & 0.241 & 0.125 \\
& & & & & & & \\
\hline
\end{tabular}




\begin{tabular}{|c|c|c|c|c|c|c|c|}
\hline State & 1984 & 1992 & Diff & State & 1984 & 1992 & Diff \\
\hline MT & 0.055 & 0.233 & 0.178 & $\mathbf{M T}$ & 0.055 & 0.230 & 0.176 \\
\hline NE & 0.170 & 0.221 & 0.051 & NE & 0.170 & 0.270 & 0.100 \\
\hline NV & 0.056 & 0.261 & 0.205 & NV & 0.056 & 0.220 & 0.164 \\
\hline NH & 0.061 & 0.167 & 0.106 & NH & 0.061 & 0.205 & 0.143 \\
\hline NJ & 0.164 & 0.223 & 0.059 & NJ & 0.164 & 0.219 & 0.056 \\
\hline $\mathbf{N M}$ & 0.088 & 0.318 & 0.230 & $\mathbf{N M}$ & 0.088 & 0.362 & 0.275 \\
\hline $\mathbf{N Y}$ & 0.286 & 0.491 & 0.205 & $\mathbf{N Y}$ & 0.286 & 0.481 & 0.194 \\
\hline $\mathrm{NC}$ & 0.068 & 0.299 & 0.231 & NC & 0.068 & 0.257 & 0.189 \\
\hline ND & 0.168 & 0.223 & 0.055 & ND & 0.168 & 0.293 & 0.125 \\
\hline $\mathrm{OH}$ & 0.173 & 0.267 & 0.094 & $\mathrm{OH}$ & 0.173 & 0.260 & 0.087 \\
\hline OK & 0.153 & 0.334 & 0.181 & OK & 0.153 & 0.245 & 0.092 \\
\hline OR & 0.060 & 0.243 & 0.183 & OR & 0.060 & 0.246 & 0.185 \\
\hline PA & 0.223 & 0.218 & -0.005 & PA & 0.223 & 0.291 & 0.068 \\
\hline RI & 0.194 & 0.292 & 0.098 & RI & 0.194 & 0.281 & 0.088 \\
\hline SC & 0.079 & 0.335 & 0.256 & SC & 0.079 & 0.324 & 0.245 \\
\hline SD & 0.050 & 0.227 & 0.177 & SD & 0.050 & 0.260 & 0.210 \\
\hline TN & 0.095 & 0.321 & 0.226 & TN & 0.095 & 0.300 & 0.206 \\
\hline $\mathrm{TX}$ & 0.069 & 0.348 & 0.279 & $\mathbf{T X}$ & 0.069 & 0.322 & 0.253 \\
\hline UT & 0.146 & 0.236 & 0.090 & UT & 0.146 & 0.252 & 0.106 \\
\hline VT & 0.192 & 0.356 & 0.164 & VT & 0.192 & 0.437 & 0.244 \\
\hline VA & 0.090 & 0.218 & 0.128 & VA & 0.090 & 0.220 & 0.130 \\
\hline WA & 0.126 & 0.246 & 0.120 & WA & 0.126 & 0.230 & 0.104 \\
\hline WV & 0.104 & 0.353 & 0.249 & WV & 0.104 & 0.331 & 0.228 \\
\hline WI & 0.266 & 0.218 & -0.048 & WI & 0.266 & 0.320 & 0.054 \\
\hline WY & 0.055 & 0.224 & 0.169 & $\mathbf{W Y}$ & 0.055 & 0.224 & 0.169 \\
\hline
\end{tabular}

Notes: Figures are fraction of children eligible for Medicaid in each state year, based on author's calculations as described in the text and in Appendix A. 


\begin{tabular}{|cccc|}
\hline \multicolumn{4}{|c|}{ Table 1: Medicaid Eligibility and Coverage } \\
\hline Year & $\begin{array}{c}\text { \% of Children } \\
\text { Eligible }\end{array}$ & $\begin{array}{c}\text { \% of Children } \\
\text { Eligible } \\
\text { Fixed Population }\end{array}$ & $\begin{array}{c}\text { \% of Children } \\
\text { Covered }\end{array}$ \\
\hline 1984 & 16.1 & 16.1 & 13.2 \\
1985 & 18.2 & 18.4 & 13.5 \\
1986 & 19.0 & 18.9 & 13.8 \\
1987 & 19.3 & 19.7 & 13.5 \\
1988 & 18.8 & 20.3 & 12.8 \\
1989 & 20.4 & 21.6 & 13.9 \\
1990 & 25.7 & 26.2 & 16.5 \\
1991 & 28.7 & 28.1 & 19.3 \\
1992 & 31.2 & 30.3 & 20.6 \\
\hline
\end{tabular}

Notes: Column 1 shows the percent of children eligible for Medicaid in each year. Column 2 shows the percentage of the 1984 sample that would have been eligible for Medicaid in each subsequent year (holding their characteristics constant and inflating income appropriately). Column 3 gives the percentage of children actually covered in each year. Figures are from the authors' calculations as described in the text and in Appendix A. 


\begin{tabular}{|c|c|c|}
\hline & $\begin{array}{l}\text { (1) } \\
\text { OLS }\end{array}$ & $\begin{array}{l}\text { (2) } \\
\text { TSLS }\end{array}$ \\
\hline Sample & All & All \\
\hline $\begin{array}{l}\text { Medicaid } \\
\text { Eligibility }\end{array}$ & $\begin{array}{c}29.77 \\
(0.019)\end{array}$ & $\begin{array}{c}22.73 \\
(1.109)\end{array}$ \\
\hline Female & $\begin{array}{l}-0.017 \\
(0.098)\end{array}$ & $\begin{array}{l}-0.003 \\
(0.098)\end{array}$ \\
\hline Black & $\begin{array}{c}9.323 \\
(0.162)\end{array}$ & $\begin{array}{c}9.555 \\
(0.166)\end{array}$ \\
\hline $\begin{array}{l}\text { Mom is High } \\
\text { School Graduate }\end{array}$ & $\begin{array}{l}-6.218 \\
(0.131)\end{array}$ & $\begin{array}{l}-6.570 \\
(0.142)\end{array}$ \\
\hline $\begin{array}{c}\text { Mom has Some } \\
\text { College }\end{array}$ & $\begin{array}{l}-7.405 \\
(0.166)\end{array}$ & $\begin{array}{l}-7.867 \\
(0.180)\end{array}$ \\
\hline $\begin{array}{c}\text { Income }> \\
\$ 10,000\end{array}$ & $\begin{array}{l}-19.09 \\
(0.191)\end{array}$ & $\begin{array}{l}-23.15 \\
(0.659)\end{array}$ \\
\hline $\begin{array}{c}\$ 10,000<\text { Inc } \\
<\$ 20,000\end{array}$ & $\begin{array}{l}-22.36 \\
(0.217)\end{array}$ & $\begin{array}{l}-27.62 \\
(0.845)\end{array}$ \\
\hline $\begin{array}{c}\$ 20,000<\text { Inc } \\
<\$ 30,000\end{array}$ & $\begin{array}{l}-23.37 \\
(0.228)\end{array}$ & $\begin{array}{l}-28.72 \\
(0.859)\end{array}$ \\
\hline $\begin{array}{c}\$ 30,000<\text { Inc } \\
<\$ 40,000\end{array}$ & $\begin{array}{l}-23.28 \\
(0.250)\end{array}$ & $\begin{array}{l}-28.60 \\
(0.863)\end{array}$ \\
\hline $\begin{array}{c}\$ 40,000<\text { Inc } \\
<\$ 50,000\end{array}$ & $\begin{array}{l}-23.12 \\
(0.250)\end{array}$ & $\begin{array}{l}-28.44 \\
(0.862)\end{array}$ \\
\hline R Squared & 0.395 & $\cdots$ \\
\hline Number Obs & 324821 & 324821 \\
\hline
\end{tabular}

Notes: Standard errors in parentheses. All regressions include full set of age, state, and year dummies. Eligibility is instrumented using simulated eligibility, matched to individuals by state, year, and age groups, as described in Part II. 


\begin{tabular}{|c|c|c|}
\hline & All & Medicaid Eligible \\
\hline \% Eligible & $\begin{array}{c}0.219 \\
(0.001)\end{array}$ & 1.000 \\
\hline \# Observations & 227169 & 49991 \\
\hline \multicolumn{3}{|l|}{ Utilization of Care } \\
\hline No Doctor's Visits Last 12 Months & $\begin{array}{c}0.194 \\
(0.001)\end{array}$ & $\begin{array}{c}0.197 \\
(0.002)\end{array}$ \\
\hline Doctor's Visit Last 2 Weeks & $\begin{array}{l}.115 \\
(0.001)\end{array}$ & $\begin{array}{c}0.118 \\
(0.001)\end{array}$ \\
\hline Any Hospitalization Last 12 Months & $\begin{array}{c}0.036 \\
(0.0004)\end{array}$ & $\begin{array}{c}0.049 \\
(0.001)\end{array}$ \\
\hline Visit to Doctor's Office Last 2 Weeks & $\begin{array}{c}0.087 \\
(0.0006)\end{array}$ & $\begin{array}{c}0.071 \\
(0.001)\end{array}$ \\
\hline $\begin{array}{l}\text { Visit to ER or Hospital Clinic } \\
\text { Lest } 2 \text { Weeks }\end{array}$ & $\begin{array}{c}0.017 \\
(0.0003)\end{array}$ & $\begin{array}{c}0.027 \\
(0.001)\end{array}$ \\
\hline $\begin{array}{l}\text { Visit to Other Site of Care } \\
\text { Last } 2 \text { Weeks }\end{array}$ & $\begin{array}{c}.015 \\
(0.0003)\end{array}$ & $\begin{array}{c}0.024 \\
(0.001)\end{array}$ \\
\hline \multicolumn{3}{|l|}{ Subjective Health Status } \\
\hline Any Activity Limitation & $\begin{array}{c}0.051 \\
(0.0005)\end{array}$ & $\begin{array}{c}0.062 \\
(0.001)\end{array}$ \\
\hline In Fair \& Poor Health & $\begin{array}{c}0.027 \\
(0.0003)\end{array}$ & $\begin{array}{c}0.051 \\
(0.001)\end{array}$ \\
\hline \multicolumn{3}{|l|}{ Family \& Child Characteristics } \\
\hline Male & $\begin{array}{c}0.513 \\
(0.001)\end{array}$ & $\begin{array}{c}0.509 \\
(0.002)\end{array}$ \\
\hline Black & $\begin{array}{c}0.180 \\
(0.001)\end{array}$ & $\begin{array}{c}0.355 \\
(0.002)\end{array}$ \\
\hline Hispanic & $\begin{array}{c}0.120 \\
(0.001)\end{array}$ & $\begin{array}{c}0.219 \\
(0.002)\end{array}$ \\
\hline Age & $\begin{array}{l}6.873 \\
(0.001)\end{array}$ & $\begin{array}{c}5.401 \\
(0.019)\end{array}$ \\
\hline Female Head/Spouse is HS Dropout & $\begin{array}{c}0.240 \\
(0.001)\end{array}$ & $\begin{array}{c}0.506 \\
(0.002)\end{array}$ \\
\hline Female Head/Spouse Has Some College & $\begin{array}{c}0.355 \\
(0.001)\end{array}$ & $\begin{array}{c}0.133 \\
(0.002)\end{array}$ \\
\hline
\end{tabular}




\begin{tabular}{|c|c|c|}
\hline & All & Medicaid Eligible \\
\hline Male Head Has Some College & $\begin{array}{c}0.342 \\
(0.001)\end{array}$ & $\begin{array}{c}0.079 \\
(0.001)\end{array}$ \\
\hline Child is Oldeat & $\begin{array}{c}0.540 \\
(0.001)\end{array}$ & $\begin{array}{c}0.429 \\
(0.002)\end{array}$ \\
\hline Number of Siblings & $\begin{array}{c}1.304 \\
(0.002)\end{array}$ & $\begin{array}{c}1.800 \\
(0.006)\end{array}$ \\
\hline No Male Head & $\begin{array}{c}0.221 \\
(0.001)\end{array}$ & $\begin{array}{c}0.505 \\
(0.002)\end{array}$ \\
\hline Mom is Respondent & $\begin{array}{c}0.295 \\
(0.001)\end{array}$ & $\begin{array}{c}0.588 \\
(0.002)\end{array}$ \\
\hline Dad is Respondent & $\begin{array}{c}0.694 \\
(0.001)\end{array}$ & $\begin{array}{c}0.411 \\
(0.002)\end{array}$ \\
\hline Other Female Relatives & $\begin{array}{c}0.043 \\
(0.0004)\end{array}$ & $\begin{array}{c}0.064 \\
(0.001)\end{array}$ \\
\hline Other Male Relatives & $\begin{array}{c}0.028 \\
(0.0004)\end{array}$ & $\begin{array}{c}0.041 \\
(0.001)\end{array}$ \\
\hline Family Income $<10000$ & $\begin{array}{c}0.137 \\
(0.001)\end{array}$ & $\begin{array}{c}0.532 \\
(0.002)\end{array}$ \\
\hline $10000<$ Inc $<20000$ & $\begin{array}{c}0.181 \\
(0.001)\end{array}$ & $\begin{array}{c}0.250 \\
(0.002)\end{array}$ \\
\hline $20000<$ Inc $<30000$ & $\begin{array}{c}0.174 \\
(0.001)\end{array}$ & $\begin{array}{c}0.055 \\
(0.001)\end{array}$ \\
\hline $30000<\operatorname{Inc}<40000$ & $\begin{array}{c}0.145 \\
(0.001)\end{array}$ & $\begin{array}{c}0.006 \\
(0.0004)\end{array}$ \\
\hline $40000<$ Inc $<50000$ & $\begin{array}{c}0.099 \\
(0.0006)\end{array}$ & $\begin{array}{c}0.0005 \\
(0.0001)\end{array}$ \\
\hline Family Income > 50000 & $\begin{array}{c}0.138 \\
(0.001)\end{array}$ & $\begin{array}{c}0 \\
(0)\end{array}$ \\
\hline Central City & $\begin{array}{c}0.260 \\
(0.001)\end{array}$ & $\begin{array}{c}0.413 \\
(0.002)\end{array}$ \\
\hline Rural & $\begin{array}{c}0.288 \\
(0.001)\end{array}$ & $\begin{array}{c}0.268 \\
(0.002)\end{array}$ \\
\hline
\end{tabular}

Notes: Source is authors' tabulations of NHIS data. Standard deviations in parentheses. 


\begin{tabular}{|c|c|c|c|c|c|c|}
\hline \multicolumn{7}{|c|}{$\begin{array}{l}\text { Table 4: Medicaid Eligibility and the Utilization of Medical Care } \\
\text { Linear Probability Models; Coefncients } 10^{2}\end{array}$} \\
\hline Dependent Var & $\begin{array}{c}\text { (1) } \\
\text { OLS } \\
\text { No Visit } \\
\text { Last Year }\end{array}$ & $\begin{array}{c}\text { (2) } \\
\text { OLS } \\
\text { Visit Last } \\
2 \text { weeks }\end{array}$ & $\begin{array}{c}\text { (3) } \\
\text { OLS } \\
\text { Hospital } \\
\text { Last Year }\end{array}$ & $\begin{array}{c}\text { (4) } \\
\text { TSLS } \\
\text { No Visit } \\
\text { Last Year }\end{array}$ & $\begin{array}{c}(5) \\
\text { TSLS } \\
\text { Visit Last } \\
2 \text { weeks }\end{array}$ & $\begin{array}{c}\text { (6) } \\
\text { TSLS } \\
\text { Hospital } \\
\text { Last Year }\end{array}$ \\
\hline $\begin{array}{l}\text { Medicaid } \\
\text { Eligibility }\end{array}$ & $\begin{array}{l}-2.549 \\
(0.294)\end{array}$ & $\begin{array}{r}-0.060 \\
(0.244)\end{array}$ & $\begin{array}{c}0.694 \\
(0.144)\end{array}$ & $\begin{array}{l}-7.901 \\
(3.060)\end{array}$ & $\begin{array}{l}3.867 \\
(2.549)\end{array}$ & $\begin{array}{c}4.169 \\
(1.506)\end{array}$ \\
\hline Male & $\begin{array}{l}-0.086 \\
(0.158)\end{array}$ & $\begin{array}{l}0.693 \\
(0.131)\end{array}$ & $\begin{array}{l}0.761 \\
(0.078)\end{array}$ & $\begin{array}{l}-0.086 \\
(0.159)\end{array}$ & $\begin{array}{c}0.692 \\
(0.131)\end{array}$ & $\begin{array}{c}0.760 \\
(0.078)\end{array}$ \\
\hline Black & $\begin{array}{l}4.126 \\
(0.248)\end{array}$ & $\begin{array}{l}-3.342 \\
(0.206)\end{array}$ & $\begin{array}{c}-0.631 \\
(0.122)\end{array}$ & $\begin{array}{c}4.289 \\
(0.265)\end{array}$ & $\begin{array}{l}-3.461 \\
(0.220)\end{array}$ & $\begin{array}{c}-0.737 \\
(0.130)\end{array}$ \\
\hline Hispanic & $\begin{array}{c}1.748 \\
(0.282)\end{array}$ & $\begin{array}{l}-0.946 \\
(0.234)\end{array}$ & $\begin{array}{c}-0.044 \\
(0.138)\end{array}$ & $\begin{array}{c}1.923 \\
(0.300)\end{array}$ & $\begin{array}{l}-1.075 \\
(0.248)\end{array}$ & $\begin{array}{c}-0.158 \\
(0.147)\end{array}$ \\
\hline $\begin{array}{c}\text { Mom is HS } \\
\text { Dropout }\end{array}$ & $\begin{array}{c}2.806 \\
(0.228)\end{array}$ & $\begin{array}{l}-0.625 \\
(0.189)\end{array}$ & $\begin{array}{c}0.280 \\
(0.111)\end{array}$ & $\begin{array}{c}3.143 \\
(0.298)\end{array}$ & $\begin{array}{l}-0.873 \\
(0.248)\end{array}$ & $\begin{array}{c}0.060 \\
(0.147)\end{array}$ \\
\hline $\begin{array}{c}\text { Mom has Some } \\
\text { College }\end{array}$ & $\begin{array}{l}-3.146 \\
(0.204)\end{array}$ & $\begin{array}{c}1.158 \\
(0.169)\end{array}$ & $\begin{array}{r}-0.234 \\
(0.100)\end{array}$ & $\begin{array}{l}-3.278 \\
(0.217)\end{array}$ & $\begin{array}{c}1.253 \\
(0.180)\end{array}$ & $\begin{array}{l}-0.150 \\
(0.106)\end{array}$ \\
\hline $\begin{array}{c}\text { Dad is HS } \\
\text { Dropout }\end{array}$ & $\begin{array}{c}3.083 \\
(0.272)\end{array}$ & $\begin{array}{l}-0.794 \\
(0.225)\end{array}$ & $\begin{array}{r}-0.216 \\
(0.133)\end{array}$ & $\begin{array}{c}3.305 \\
(0.300)\end{array}$ & $\begin{array}{l}-0.958 \\
(0.249)\end{array}$ & $\begin{array}{c}-0.361 \\
(0.147)\end{array}$ \\
\hline $\begin{array}{c}\text { Dad has Some } \\
\text { College }\end{array}$ & $\begin{array}{l}-2.364 \\
(0.227)\end{array}$ & $\begin{array}{c}0.675 \\
(0.188)\end{array}$ & $\begin{array}{r}-0.254 \\
(0.111)\end{array}$ & $\begin{array}{l}-2.354 \\
(0.227)\end{array}$ & $\begin{array}{c}0.667 \\
(0.188)\end{array}$ & $\begin{array}{l}-0.261 \\
(0.111)\end{array}$ \\
\hline Child is Oldest & $\begin{array}{c}-2.531 \\
(0.193)\end{array}$ & $\begin{array}{c}1.0060(0 . \\
160)\end{array}$ & $\begin{array}{c}-0.059 \\
(0.094)\end{array}$ & $\begin{array}{c}-2.401 \\
(0.206)\end{array}$ & $\begin{array}{c}0.912 \\
(0.171)\end{array}$ & $\begin{array}{c}-0.142 \\
(0.101)\end{array}$ \\
\hline $\begin{array}{l}\text { Number of } \\
\text { Siblings }\end{array}$ & $\begin{array}{c}1.688 \\
(0.087)\end{array}$ & $\begin{array}{c}-0.660 \\
(0.072)\end{array}$ & $\begin{array}{c}-0.228 \\
(0.042)\end{array}$ & $\begin{array}{c}2.008 \\
(0.202)\end{array}$ & $\begin{array}{c}0.895 \\
(0.168)\end{array}$ & $\begin{array}{c}-0.436 \\
(0.099)\end{array}$ \\
\hline No Male Head & $\begin{array}{l}-5.222 \\
(0.383)\end{array}$ & $\begin{array}{c}2.162 \\
(0.318)\end{array}$ & $\begin{array}{c}0.571 \\
(0.188)\end{array}$ & $\begin{array}{l}-5.029 \\
(0.399)\end{array}$ & $\begin{array}{c}2.021 \\
(0.331)\end{array}$ & $\begin{array}{c}0.446 \\
(0.195)\end{array}$ \\
\hline $\begin{array}{c}\text { Mom is } \\
\text { Respondent }\end{array}$ & $\begin{array}{l}-0.168 \\
(0.609)\end{array}$ & $\begin{array}{c}1.337 \\
(0.504)\end{array}$ & $\begin{array}{l}-0.504 \\
(0.298)\end{array}$ & $\begin{array}{c}0.004 \\
(0.617)\end{array}$ & $\begin{array}{c}1.209 \\
(0.511)\end{array}$ & $\begin{array}{l}-0.617 \\
(0.302)\end{array}$ \\
\hline $\begin{array}{c}\text { Dad is } \\
\text { Respondent }\end{array}$ & $\begin{array}{c}1.197 \\
(0.665)\end{array}$ & $\begin{array}{c}-0.705 \\
(0.551)\end{array}$ & $\begin{array}{c}-0.888 \\
(0.326)\end{array}$ & $\begin{array}{c}1.321 \\
(0.670)\end{array}$ & $\begin{array}{c}-0.613 \\
(0.555)\end{array}$ & $\begin{array}{c}-.970 \\
(0.328)\end{array}$ \\
\hline $\begin{array}{c}\text { Other Female } \\
\text { Relative }\end{array}$ & $\begin{array}{c}0.450 \\
(0.392)\end{array}$ & $\begin{array}{c}-0.279 \\
(0.0351\end{array}$ & $\begin{array}{l}-0.225 \\
(0.192)\end{array}$ & $\begin{array}{c}0.587 \\
(0.400)\end{array}$ & $\begin{array}{c}-0.379 \\
(0.332)\end{array}$ & $\begin{array}{c}-0.314 \\
(0.196)\end{array}$ \\
\hline $\begin{array}{c}\text { Other Male } \\
\text { Relative }\end{array}$ & $\begin{array}{c}2.570 \\
(0.487)\end{array}$ & $\begin{array}{c}-0.807 \\
(0.403)\end{array}$ & $\begin{array}{l}-0.100 \\
(0.238)\end{array}$ & $\begin{array}{c}2.632 \\
(0.488)\end{array}$ & $\begin{array}{l}-0.853 \\
(0.405)\end{array}$ & $\begin{array}{l}-0.141 \\
(0.239)\end{array}$ \\
\hline
\end{tabular}


Table 4: Medicaid Eligibility and the Utilization of Medical Care, Continued Linear Probability Models; Coefncients ${ }^{* 10^{2}}$

\begin{tabular}{|cccc|ccc||}
\hline & $(1)$ & $(2)$ & $(3)$ & $(4)$ & $(2)$ & $(6)$ \\
Dependent Var & OLS & OLS & OLS & TSLS & TSLS & TSLS \\
& $\begin{array}{c}\text { No Visit } \\
\text { Last Year }\end{array}$ & $\begin{array}{c}\text { Visit Last } \\
\text { 2 weeks }\end{array}$ & $\begin{array}{c}\text { Hospital } \\
\text { Last Year }\end{array}$ & $\begin{array}{c}\text { No Visit } \\
\text { Last Year }\end{array}$ & $\begin{array}{c}\text { Visit Last } \\
\text { 2 weeks }\end{array}$ & $\begin{array}{c}\text { Hospital } \\
\text { Last Year }\end{array}$ \\
\hline Income $<10000$ & -0.980 & 1.995 & 0.735 & 1.748 & 0.005 & -1.034 \\
& $(0.367)$ & $(0.304)$ & $(0.179)$ & $(1.595)$ & $(1.327)$ & $(0.784)$ \\
$10000<$ Inc $<$ & -0.651 & 0.839 & 0.450 & -0.534 & 0.754 & 0.376 \\
20000 & $(0.296)$ & $(0.245)$ & $(0.145)$ & $(0.304)$ & $(0.252)$ & $(0.149)$ \\
$20000<$ Inc $<$ & -2.767 & 1.266 & 0.547 & -3.639 & 1.907 & 1.114 \\
30000 & $(0.303)$ & $(0.245)$ & $(0.148)$ & $(0.582)$ & $(0.485)$ & $(0.286)$ \\
$30000<$ Inc $<$ & -4.685 & 1.839 & 0.453 & -5.791 & 2.261 & 1.172 \\
40000 & $(0.321)$ & $(0.266)$ & $(0.157)$ & $(0.707)$ & $(0.588)$ & $(0.348)$ \\
$40000<$ Inc $<$ & -6.266 & 2.455 & 0.333 & -7.384 & 3.276 & 1.059 \\
50000 & $(0.355)$ & $(0.294)$ & $(0.174)$ & $(0.729)$ & $(0.607)$ & $(0.358)$ \\
Family Income $>$ & -7.007 & 3.266 & 0.183 & -8.173 & 4.122 & 0.941 \\
50000 & $(0.341)$ & $(0.283)$ & $(0.167)$ & $(0.746)$ & $(0.621)$ & $(0.367)$ \\
Central City & -1.071 & 0.235 & -0.183 & -0.937 & 0.136 & -0.270 \\
& $(0.214)$ & $(0.178)$ & $(0.105)$ & $(0.228)$ & $(0.189)$ & $(0.112)$ \\
Rural & 2.363 & -0.282 & 0.726 & 2.411 & -0.318 & 0.694 \\
R Squared & $(0.224)$ & $(0.186)$ & $(0.110)$ & $(0.226)$ & $(0.188)$ & $(0.111)$ \\
Number of Obs & 226603 & 227169 & 227169 & 226603 & 227169 & 227169 \\
\hline \hline
\end{tabular}

Notes: Standard errors in parentheses. All regressions also include an intercept; dummy variables for each state, calendar year, and year of age; season dummies; interactions between calendar year and year of age dummies; and interactions between year of age and state dummies. Eligibility is instrumented using simulated eligibility calculated using the CPS, and matched to individuals by state, year, and age. 


\begin{tabular}{|cccc|}
\hline \multicolumn{4}{|c|}{$\begin{array}{c}\text { Table 5: Medicaid Eligibility and the Site of Care } \\
\text { All Regressions Run as Instrumental Variables } \\
\text { Medicaid Eligibility Coefficient and Means are *100 }\end{array}$} \\
\hline $\begin{array}{c}(1) \\
\text { Doctor's Office }\end{array}$ & $\begin{array}{c}(2) \\
\text { ER or Hospital } \\
\text { Outpatient Clinic }\end{array}$ & $\begin{array}{c}(3) \\
\text { Other Site }\end{array}$ \\
\hline Medicaid Eligibility & $\begin{array}{c}4.190 \\
(2.247)\end{array}$ & 2.083 & -1.711 \\
Mean of Dependent Var & 8.707 & $(1.041)$ & $(.980)$ \\
& & 1.666 & 1.473 \\
Number of Obs & 227169 & & 227169 \\
\hline
\end{tabular}

Notes: Standard errors in parentheses. All regressions also include all the variables listed in Table 4, as well as an intercept; dummy variables for each state, calendar year, and year of age; season dummies; interactions between calendar year and year of age dummies; and interactions between year of age and state dummies. Eligibility is instrumented using simulated eligibility calculated from the CPS, and matched to individuals by state, year, and age. 


\begin{tabular}{|c|c|c|c|c|}
\hline \multicolumn{5}{|c|}{$\begin{array}{l}\text { Table 6: Medicaid Eligibility and Health Status } \\
\text { Linear Probability Models; Coefficients } * 10^{2}\end{array}$} \\
\hline & $\begin{array}{l}\text { (1) } \\
\text { OLS }\end{array}$ & $\begin{array}{l}\text { (2) } \\
\text { OLS }\end{array}$ & $\begin{array}{c}\text { (3) } \\
\text { TSLS }\end{array}$ & $\begin{array}{c}\text { (4) } \\
\text { TSLS }\end{array}$ \\
\hline Dependent Var: & $\begin{array}{l}\text { Fair or } \\
\text { Poor Hlth }\end{array}$ & $\begin{array}{l}\text { Activity } \\
\text { Limit }\end{array}$ & $\begin{array}{l}\text { Fair or } \\
\text { Poor Hlth }\end{array}$ & $\begin{array}{l}\text { Activity } \\
\text { Limit }\end{array}$ \\
\hline $\begin{array}{l}\text { Medicaid } \\
\text { Eligibility }\end{array}$ & $\begin{array}{c}0.698 \\
(0.125)\end{array}$ & $\begin{array}{l}-0.155 \\
(0.170)\end{array}$ & $\begin{array}{r}1.193 \\
(1.301)\end{array}$ & $\begin{array}{c}2.494 \\
(1.781)\end{array}$ \\
\hline Males & $\begin{array}{c}0.246 \\
(0.067)\end{array}$ & $\begin{array}{c}1.966 \\
(0.092)\end{array}$ & $\begin{array}{c}0.246 \\
(0.067)\end{array}$ & $\begin{array}{l}1.966 \\
(0.092)\end{array}$ \\
\hline Black & $\begin{array}{l}0.970 \\
(0.105)\end{array}$ & $\begin{array}{l}-0.725 \\
(0.144)\end{array}$ & $\begin{array}{c}0.955 \\
(0.112)\end{array}$ & $\begin{array}{l}-0.805 \\
(0.154)\end{array}$ \\
\hline Hispanic & $\begin{array}{c}0.689 \\
(0.119)\end{array}$ & $\begin{array}{l}-1.226 \\
(0.163)\end{array}$ & $\begin{array}{c}0.673 \\
(0.127)\end{array}$ & $\begin{array}{c}-1.313 \\
(0.174)\end{array}$ \\
\hline $\begin{array}{c}\text { Mom is HS } \\
\text { Dropout }\end{array}$ & $\begin{array}{c}1.349 \\
(0.096)\end{array}$ & $\begin{array}{c}0.799 \\
(0.132)\end{array}$ & $\begin{array}{c}1.318 \\
(0.127)\end{array}$ & $\begin{array}{c}0.631 \\
(0.173)\end{array}$ \\
\hline $\begin{array}{c}\text { Mom has Some } \\
\text { College }\end{array}$ & $\begin{array}{r}-0.400 \\
(0.086)\end{array}$ & $\begin{array}{c}0.050 \\
(0.118)\end{array}$ & $\begin{array}{c}-0.388 \\
(0.092)\end{array}$ & $\begin{array}{c}0.114 \\
(0.126)\end{array}$ \\
\hline $\begin{array}{c}\text { Dad is HS } \\
\text { Dropout }\end{array}$ & $\begin{array}{c}0.550 \\
(0.115)\end{array}$ & $\begin{array}{c}0.504 \\
(0.157)\end{array}$ & $\begin{array}{c}0.530 \\
(0.127)\end{array}$ & $\begin{array}{c}0.393 \\
(0.174)\end{array}$ \\
\hline $\begin{array}{c}\text { Dad has Some } \\
\text { College }\end{array}$ & $\begin{array}{l}-0.209 \\
(0.096)\end{array}$ & $\begin{array}{c}-0.295 \\
(0.131)\end{array}$ & $\begin{array}{l}-0.210 \\
(0.096)\end{array}$ & $\begin{array}{l}-0.300 \\
(0.131)\end{array}$ \\
\hline Child is Oldest & $\begin{array}{c}-0.642 \\
(0.082)\end{array}$ & $\begin{array}{c}0.025 \\
(0.112)\end{array}$ & $\begin{array}{l}-0.654 \\
(0.087)\end{array}$ & $\begin{array}{l}-0.039 \\
(0.120)\end{array}$ \\
\hline $\begin{array}{l}\text { Number of } \\
\text { Siblings }\end{array}$ & $\begin{array}{c}-0.086 \\
(0.037)\end{array}$ & $\begin{array}{l}-0.079 \\
(0.050)\end{array}$ & $\begin{array}{c}-0.116 \\
(0.086)\end{array}$ & $\begin{array}{c}-0.237 \\
(0.117)\end{array}$ \\
\hline No Male Head & $\begin{array}{c}-0.063 \\
(0.162)\end{array}$ & $\begin{array}{c}0.292 \\
(0.222)\end{array}$ & $\begin{array}{c}-0.081 \\
(0.169)\end{array}$ & $\begin{array}{c}0.197 \\
(0.231)\end{array}$ \\
\hline $\begin{array}{c}\text { Mom is } \\
\text { Respondent }\end{array}$ & $\begin{array}{c}1.268 \\
(0.258)\end{array}$ & $\begin{array}{c}0.875 \\
(0.352)\end{array}$ & $\begin{array}{c}1.252 \\
(0.261)\end{array}$ & $\begin{array}{c}0.788 \\
(0.357)\end{array}$ \\
\hline $\begin{array}{c}\text { Dad is } \\
\text { Respondent }\end{array}$ & $\begin{array}{c}0.506 \\
(0.282)\end{array}$ & $\begin{array}{c}0.097 \\
(0.385)\end{array}$ & $\begin{array}{c}0.495 \\
(0.283)\end{array}$ & $\begin{array}{c}0.035 \\
(0.388)\end{array}$ \\
\hline $\begin{array}{c}\text { Other Female } \\
\text { Relative }\end{array}$ & $\begin{array}{l}-0.153 \\
(0.166)\end{array}$ & $\begin{array}{l}-0.123 \\
(0.227)\end{array}$ & $\begin{array}{c}-0.166 \\
(0.169)\end{array}$ & $\begin{array}{c}-0.191 \\
(0.232)\end{array}$ \\
\hline $\begin{array}{c}\text { Other Male } \\
\text { Relative }\end{array}$ & $\begin{array}{l}-0.017 \\
(0.206)\end{array}$ & $\begin{array}{c}0.011 \\
(0.282)\end{array}$ & $\begin{array}{l}-0.023 \\
(0.207)\end{array}$ & $\begin{array}{c}-0.020 \\
(0.283)\end{array}$ \\
\hline
\end{tabular}




\begin{tabular}{|c|c|c|c|c|}
\hline \multicolumn{5}{|c|}{$\begin{array}{l}\text { Table 6: Medicaid Eligibility and Health Status, Continued } \\
\text { Unear Probability Models; Coefricients } * 10^{2}\end{array}$} \\
\hline & $\begin{array}{l}\text { (1) } \\
\text { OLS }\end{array}$ & $\begin{array}{l}\text { (2) } \\
\text { OLS }\end{array}$ & $\begin{array}{c}\text { (3) } \\
\text { TSLS }\end{array}$ & $\begin{array}{c}\text { (4) } \\
\text { TSLS }\end{array}$ \\
\hline Dependent Var: & $\begin{array}{c}\text { Fair or } \\
\text { Poor Hlth }\end{array}$ & $\begin{array}{c}\text { Activity } \\
\text { Limit }\end{array}$ & $\begin{array}{c}\text { Fair or } \\
\text { Poor Hlth }\end{array}$ & $\begin{array}{c}\text { Activity } \\
\text { Limit }\end{array}$ \\
\hline Income $<10000$ & $\begin{array}{l}1.443 \\
(0.155)\end{array}$ & $\begin{array}{l}3.516 \\
(0.212)\end{array}$ & $\begin{array}{c}1.191 \\
(0.677)\end{array}$ & $\begin{array}{c}2.167 \\
(0.927)\end{array}$ \\
\hline $\begin{array}{c}10000<\text { Inc }< \\
20000\end{array}$ & $\begin{array}{c}0.280 \\
(0.125)\end{array}$ & $\begin{array}{c}1.784 \\
(0.171)\end{array}$ & $\begin{array}{l}0.270 \\
(0.128)\end{array}$ & $\begin{array}{c}1.727 \\
(0.176)\end{array}$ \\
\hline $\begin{array}{c}20000<\text { Inc }< \\
30000\end{array}$ & $\begin{array}{l}-0.247 \\
(0.128)\end{array}$ & $\begin{array}{c}0.833 \\
(0.176)\end{array}$ & $\begin{array}{l}-0.166 \\
(0.247)\end{array}$ & $\begin{array}{c}1.265 \\
(0.339)\end{array}$ \\
\hline $\begin{array}{c}30000<\text { Inc }< \\
40000\end{array}$ & $\begin{array}{l}-0.409 \\
(0.136)\end{array}$ & $\begin{array}{c}0.417 \\
(0.186)\end{array}$ & $\begin{array}{l}-0.307 \\
(0.300)\end{array}$ & $\begin{array}{c}.965 \\
(0.411)\end{array}$ \\
\hline $\begin{array}{c}40000<\text { Inc }< \\
50000\end{array}$ & $\begin{array}{l}-0.466 \\
(0.150)\end{array}$ & $\begin{array}{l}-0.013 \\
(0.206)\end{array}$ & $\begin{array}{l}-0.362 \\
(0.310)\end{array}$ & $\begin{array}{r}0.541 \\
(0.424)\end{array}$ \\
\hline $\begin{array}{l}\text { Family Income }> \\
50000\end{array}$ & $\begin{array}{l}-0.468 \\
(0.144)\end{array}$ & $\begin{array}{l}-0.406 \\
(0.198)\end{array}$ & $\begin{array}{l}-0.360 \\
(0.317)\end{array}$ & $\begin{array}{r}0.171 \\
(0.434)\end{array}$ \\
\hline Central City & $\begin{array}{l}-0.067 \\
(0.091)\end{array}$ & $\begin{array}{l}-0.059 \\
(0.124)\end{array}$ & $\begin{array}{l}-0.079 \\
(0.097)\end{array}$ & $\begin{array}{l}-0.126 \\
(0.132)\end{array}$ \\
\hline Rural & $\begin{array}{c}0.173 \\
(0.095)\end{array}$ & $\begin{array}{c}0.037 \\
(0.130)\end{array}$ & $\begin{array}{c}0.168 \\
(0.096)\end{array}$ & $\begin{array}{c}0.013 \\
(0.131)\end{array}$ \\
\hline R Squared & 0.018 & 0.023 & $\ldots$ & $\ldots$ \\
\hline Number of Obs & 227169 & 227169 & 227169 & 227169 \\
\hline
\end{tabular}

Notes: Standard errors in parentheses. All regressions also include an intercept; dummy variables for each state, calendar year, and year of age; season dummies; interactions between calendar year and year of age dummies; and interactions between year of age and state dummies. Eligibility is instrumented using simulated simulated eligibility calculated using the CPS, and matched to individuals by state, year, and age. 


\begin{tabular}{|c|c|c|c|}
\hline \multicolumn{4}{|c|}{$\begin{array}{l}\text { Table 7: Effects of Medicaid Eligibility on Child Mortality } \\
\text { Dependent Variable is Deaths per } 10000 \text { children }\end{array}$} \\
\hline & $\begin{array}{l}\text { (1) } \\
\text { All Kids }\end{array}$ & $\begin{array}{l}\text { (2) } \\
\text { White }\end{array}$ & $\begin{array}{c}(3) \\
\text { Black }\end{array}$ \\
\hline \% Eligible & $\begin{array}{l}-0.976 \\
(0.449)\end{array}$ & $\begin{array}{l}-0.354 \\
(0.566)\end{array}$ & $\begin{array}{l}-1.619 \\
(1.112)\end{array}$ \\
\hline $\begin{array}{l}\text { Estimated Cost Per } \\
\text { Life Saved (\$) }\end{array}$ & $\$ 2,099,831$ & $\$ 6,038,813$ & $\$ 1,426,263$ \\
\hline R Squared & 0.940 & 0.908 & 0.831 \\
\hline Mean of Dep Var & 3.291 & 3.005 & 4.888 \\
\hline Number of Obs & 816 & 816 & 816 \\
\hline
\end{tabular}

Notes: Standard errors in parentheses. Dependent variable is death rate per 10000 children in state/year/race/age group, where age groups are 1-4 years old and 5-14 years old. Regressions run as instrumental variables, where $\%$ eligible in state/year/age group cell is instrumented using simulated eligibility in that cell. Regressions include state, year, and age group dummies, interactions of state dummies with age group dummy, and age-specific time trends. Regressions are weighted by number of children in the state/year/race/age cell. Estimated cost per life saved uses race-specific takeup rates from Table 2 , and cost estimate of $\$ 902$ per child covered by Medicaid. 


\begin{tabular}{|c|c|c|c|c|c|c|}
\hline \multicolumn{7}{|c|}{$\begin{array}{l}\text { Table 8: Utilimation Efrects By Difierent Groups } \\
\text { TSLS; All Coefincients and Means times } 10^{2}\end{array}$} \\
\hline \multirow[t]{2}{*}{ Utilization } & \multicolumn{3}{|c|}{ Black } & \multicolumn{3}{|c|}{ Non-Black } \\
\hline & $\begin{array}{l}\text { No Visit } \\
\text { Last Year }\end{array}$ & $\begin{array}{l}\text { Visit Last } \\
2 \text { Weeks }\end{array}$ & $\begin{array}{c}\text { Hospital } \\
\text { Admit }\end{array}$ & $\begin{array}{l}\text { No Visit } \\
\text { Lest Year }\end{array}$ & $\begin{array}{l}\text { Visit Last } \\
2 \text { Weeks }\end{array}$ & $\begin{array}{c}\text { Hospital } \\
\text { Admit }\end{array}$ \\
\hline Medicaid Elig & $\begin{array}{r}-11.554 \\
(6.424)\end{array}$ & $\begin{array}{c}9.017 \\
(4.470)\end{array}$ & $\begin{array}{c}3.586 \\
(2.957)\end{array}$ & $\begin{array}{c}-5.864 \\
(3.789)\end{array}$ & $\begin{array}{c}1.761 \\
(3.278)\end{array}$ & $\begin{array}{c}4.029 \\
(1.895)\end{array}$ \\
\hline Mean for Race & 23.66 & 8.851 & 3.642 & 18.50 & 12.059 & 3.594 \\
\hline R Squared & 0.122 & 0.055 & 0.043 & 0.096 & 0.044 & 0.025 \\
\hline Number of Obs. & 40848 & 40967 & 40967 & 185679 & 186202 & 186202 \\
\hline \multirow[t]{2}{*}{ Site of Care } & \multicolumn{3}{|c|}{ Btack } & \multicolumn{3}{|c|}{ Non-Black } \\
\hline & $\begin{array}{l}\text { Doctor's } \\
\text { Office }\end{array}$ & $\begin{array}{l}\text { Hosp ER } \\
\text { or Clinic }\end{array}$ & Other & $\begin{array}{l}\text { Doctor's } \\
\text { Office }\end{array}$ & $\begin{array}{l}\text { Hosp ER } \\
\text { or Clinic }\end{array}$ & Other \\
\hline Medicaid Elig & $\begin{array}{c}1.500 \\
(3.444)\end{array}$ & $\begin{array}{l}5.335 \\
(2.384)\end{array}$ & $\begin{array}{c}2.839 \\
(2.127)\end{array}$ & $\begin{array}{c}3.368 \\
(2.959)\end{array}$ & $\begin{array}{c}2.545 \\
(1.258)\end{array}$ & $\begin{array}{c}-3.047 \\
(1.205)\end{array}$ \\
\hline Mean for Race & 5.031 & 2.282 & 2.819 & 9.515 & 1.531 & 1.397 \\
\hline R Squared & 0.045 & 0.029 & 0.029 & 0.042 & 0.012 & 0.011 \\
\hline Number of Obs. & 40967 & 40967 & 40967 & 186202 & 186202 & 186202 \\
\hline \multirow[t]{2}{*}{ Utilization } & \multicolumn{3}{|c|}{ Dropout } & \multicolumn{3}{|c|}{ Non-Dropout } \\
\hline & $\begin{array}{l}\text { No Visit } \\
\text { Last Year }\end{array}$ & $\begin{array}{l}\text { Visit Last } \\
2 \text { Weeks }\end{array}$ & $\begin{array}{l}\text { Hospital } \\
\text { Admit }\end{array}$ & $\begin{array}{l}\text { No Visit } \\
\text { Last Year }\end{array}$ & $\begin{array}{l}\text { Visit Last } \\
2 \text { Weeks }\end{array}$ & $\begin{array}{c}\text { Hospital } \\
\text { Admit }\end{array}$ \\
\hline Medicajd Elig & $\begin{array}{l}-10.984 \\
(4.504)\end{array}$ & $\begin{array}{c}2.879 \\
(3.089)\end{array}$ & $\begin{array}{c}4.493 \\
(2.093)\end{array}$ & $\begin{array}{l}-5.928 \\
(4.124)\end{array}$ & $\begin{array}{c}4.685 \\
(3.668)\end{array}$ & $\begin{array}{c}5.110 \\
(2.073)\end{array}$ \\
\hline Mean by Ed. & 26.18 & 9.398 & 4.032 & 17.300 & 12.128 & 3.467 \\
\hline R Squared & 0.110 & 0.051 & 0.044 & 0.089 & 0.045 & 0.023 \\
\hline Number of Obs. & 54276 & 54467 & 54467 & 172252 & 172702 & 172702 \\
\hline \multirow[t]{2}{*}{ Site of Care } & \multicolumn{3}{|c|}{ Dropout } & \multicolumn{3}{|c|}{ Non-Dropout } \\
\hline & $\begin{array}{l}\text { Doctor's } \\
\text { Office }\end{array}$ & $\begin{array}{l}\text { Hosp ER } \\
\text { or Clinic }\end{array}$ & Other & $\begin{array}{l}\text { Doctor's } \\
\text { Office }\end{array}$ & $\begin{array}{l}\text { Hosp ER } \\
\text { or Clinic }\end{array}$ & Other \\
\hline Medicaid Elig & $\begin{array}{c}1.368 \\
(2.490)\end{array}$ & $\begin{array}{c}3.514 \\
(1.573)\end{array}$ & $\begin{array}{l}-0.437 \\
(1.407)\end{array}$ & $\begin{array}{c}6.267 \\
(3.319)\end{array}$ & $\begin{array}{c}0.914 \\
(1.388)\end{array}$ & $\begin{array}{c}-1.843 \\
(1.336)\end{array}$ \\
\hline Mean by Ed. & 5.829 & 2.187 & 1.752 & 9.614 & 1.502 & 1.385 \\
\hline R Squared & 0.043 & 0.024 & 0.025 & 0.043 & 0.013 & .012 \\
\hline Number of Obs. & 54467 & 54467 & 54467 & 172702 & 172702 & 172702 \\
\hline
\end{tabular}

Notes: Standard errors in parentheses. Eligibility is instrumented using the simulated fraction eligible in each race, state, age, and year or in each education group, state, age, and year, calculated using the CPS. All regressions include the full set of control variables included in Table 4 and described in the footnote to that Table. 